\title{
Methane Production from Carbondioxide in Polluted Areas Using Graphene Doped Ni/ NiO Nanocomposite via Photocatalysis
}

\author{
Advances in Earth and Environmental Science
}

Research Article

Delia Teresa Sponza*, Rukiye Öztekin

Dokuz Eylül University, Engineering Faculty, Environmental Engineering Department, Buca-İzmir Turkey

\author{
*Correspondence authors \\ Delia Teresa Sponza \\ Dokuz Eylül University \\ Engineering Faculty \\ Environmental Engineering Department \\ Buca -İzmir Turkey
}

Submitted : 23 Sept 2021 ; Published : 8 Oct 2021

\begin{abstract}
Background: Photocatalysis for the production of solar fuels and particularly to perform $\mathrm{CO}_{2}$ reduction with a sufficiently high efficiency depends to the presence of $\mathrm{H}_{2}$ and absence of $\mathrm{H}_{2} \mathrm{O}$ using graphene doped $\mathrm{Ni} / \mathrm{NiO}$ nanocomposite.
\end{abstract}

Objective: To examine the methane production from carbondioxide in polluted areas using graphene doped Ni/ $\mathrm{NiO}$ nanocomposite via photocatalysis with the use of dimethylaniline and xylene as electron donors.

Methods: With $2 \mathrm{mg} / \mathrm{l}$ graphene doped $\mathrm{Ni} / \mathrm{NiO}$ nanocomposite with a Ni content of $19 \%$ wt from $786 \mu \mathrm{mol} / \mathrm{h} \mathrm{CO}$ gas $563 \mu \mathrm{l} \mathrm{CH} / \mathrm{g}$ Ni.h was obtained at $1600 \mathrm{C}$ temperature and the quantum yield was detected as $1.99 \%$. It was found that $\mathrm{H}_{2} \mathrm{O}$ has a negative influence on the photocatalytic activity. Under continuous flow operation, water molecules were easier desorbed from the graphene doped $\mathrm{Ni} / \mathrm{NiO}$ photocatalyst

Results: The maximum $\mathrm{CH}_{4}$ production rate was $650 \mu \mathrm{l} / \mathrm{h}$ for $2.4 \mathrm{mg}$ of graphene doped $\mathrm{Ni} / \mathrm{NiO}$ nanocomposite after a detectione time of $17 \mathrm{~min}$. Dimethylaniline and xylene were used as electron donors and $1.2 \mathrm{ml} / \mathrm{l}$ dimethylaniline and $0.9 \mathrm{ml} / \mathrm{l}$ xylene enhanced the $\mathrm{CH}_{4}$ productions by $8 \%$ and $12 \%$ as quenching factor.

Conclusion: Photocatalysis methods was effected for methane production from carbondioxide in polluted areas using graphene doped $\mathrm{Ni} / \mathrm{NiO}$ nanocomposite with the use of dimethylaniline and xylene as electron donors.

Keywords: Carbondioxide; graphene doped Ni/NiO; methane; nanocomposite; nanoparticle; photocatalysis.

\section{Introduction}

The continuous increase in atmospheric $\mathrm{CO}_{2}$ concentration is considered to be a key driver that induces climate change [1]. The prospect of unwanted climate change or climate heatingdesertification has compelled investigations into the means to normalize atmospheric $\mathrm{CO}_{2}$ concentrations. As is well known, $\mathrm{CO}_{2}$ is a highly stable molecule, requiring significant energy input for its reduction [2]. In this regard, sunlight is considered to be the most useful energy source for promoting $\mathrm{CO}_{2}$ conversion into useful hydrocarbon products, such as methane or ethane, offering the possibility of turning sunlight into fuels compatible with the current energy infrastructure [3].

Diminishing fossil fuel resources and increasing the atmospheric level of $\mathrm{CO}_{2}$ have raised great concerns in recent years regarding future energy supply, and controlling the effects on global climate [4-6]. Natural photosynthesis is a process in which $\mathrm{CO}_{2}$ is reduced in the presence of water, and carbohydrates and oxygen are produced, which is a solar to chemical energy conversion. This natural process has attracted a great deal of attention by researchers as a promising strategy to supply alternative energy and response the demand for global energy [5,6]. More than 100 years ago, Giacomo Ciamician suggested to implement the science of photosynthesis for designing solar fuels [7]. Given that, the photocatalytic reduction of $\mathrm{CO}_{2}$ into hydrocarbons, which is so-called artificial photosynthesis, has been considered as an efficient approach [5]. Being thermodynamically stable (bond enthalpy of $\mathrm{C}=\mathrm{O}$ in $\mathrm{CO}_{2}$ is $+805 \mathrm{~kJ} / \mathrm{mol}$ ), and unable to absorb light in the wavelengths of $200-900 \mathrm{~nm}$, photoreduction of $\mathrm{CO}_{2}$ is a difficult task, and needs an appropriate photosensitizer, such as a semiconductor catalyst. Despite the difficulties accompanied by this process, the potential rewards are well worth a try [8]. Therefore, much more efforts have been put in practice to attain the following goals:

1. reducing the complications of global warming, resulted from the increased atmospheric $\mathrm{CO}_{2}$ concentration;

2. utilization of clean hydrocarbon fuels, such as methane, methanol, and ethane, as fossil fuel alternatives; and 
3. developing facile and clean methods using sunlight as unlimited source of energy [9].

The photoreduction of $\mathrm{CO}_{2}$ consists of multi-electron steps, which leads to various products such as $\mathrm{CO}, \mathrm{CH} 4$, higher hydrocarbons, alcohols, aldehydes, and carboxylic acids [10]. The mechanism of this process is rather complex, so that trying the potential pathways, simultaneously terminates to different products. This has inspired many researchers to focus on investigating the mechanism and controlling the selectivity of the reaction. The following criteria are generally required for an effective system used for photoreduction of $\mathrm{CO}_{2}$ :

1. more positive redox potential for the photo-induced holes on the valence band (VB) of the semiconductor compared to the redox potential of $\mathrm{O}_{2} / \mathrm{H}_{2} \mathrm{O}$;

2. more negative redox potential for the photo-generated electrons on the conduction band (CB) of the semiconductor in relation to the redox potential value of $\mathrm{CO}_{2}$ to the formed reduced products (e.g. $\mathrm{CH}_{4} / \mathrm{CO}_{2}$ );

3. effective adsorption of $\mathrm{CO}_{2}$ or $\mathrm{CO}_{3}^{-2}$ on the surface of the photocatalyst; iv) highly stable photocatalyst $[11,12]$.

Equations (1) to (8) present the multistep reactions involved in the reduction of $\mathrm{CO}_{2}$. As can be seen, the process involves several multiple electron transfer steps, which makes it kinetically difficult to progress. The reduction potentials for photoreduction of $\mathrm{CO}_{2}$ in the presence of $\mathrm{H}_{2} \mathrm{O}$ into several products are given versus NHE at $\mathrm{pH}=7.0$ (Eqs. 1-8):

$$
\begin{array}{lc}
\mathrm{CO}_{2}+\overline{\mathrm{e}} \rightarrow \mathrm{Co}_{2} \cdot & \mathrm{E}=-1.90 \mathrm{~V} \\
\mathrm{CO}_{2}+2 \mathrm{H}^{+}+2 \overline{\mathrm{e}} \rightarrow \mathrm{HCOOH} & \mathrm{E}=-0.61 \mathrm{~V} \\
\mathrm{CO}_{2}+2 \mathrm{H}^{+}+2 \overline{\mathrm{e}} \rightarrow \mathrm{CO}+\mathrm{H}_{2} \mathrm{O} & \mathrm{E}=-0.53 \mathrm{~V} \\
\mathrm{CO}_{2}+4 \mathrm{H}^{+}+4 \overline{\mathrm{e}} \rightarrow \mathrm{HCHO}+\mathrm{H}_{2} \mathrm{O} & \mathrm{E}=-0.48 \mathrm{~V} \\
\mathrm{CO}_{2}+6 \mathrm{H}^{+}+6 \overline{\mathrm{e}} \rightarrow \mathrm{CH}_{3} \mathrm{OH}+\mathrm{H}_{2} \mathrm{O} & \mathrm{E}=-0.38 \mathrm{~V} \\
\mathrm{CO}_{2}+8 \mathrm{H}^{+}+8 \overline{\mathrm{e}} \rightarrow \mathrm{CH}_{4} \mathrm{OH}+2 \mathrm{H}_{2} \mathrm{O} & \mathrm{E}=-0.24 \mathrm{~V} \\
2 \mathrm{H}^{+}+2 \overline{\mathrm{e}} \rightarrow \mathrm{H}_{2} & \mathrm{E}=-0.41 \mathrm{~V} \\
2 \mathrm{H}_{2} \mathrm{O}+4 h^{+} \rightarrow \mathrm{O}_{2}+4 \mathrm{H}^{+} & \mathrm{E}=0.82 \mathrm{~V}
\end{array}
$$

One of themost important objectives in $\mathrm{CO}_{2}$ photoreduction studies is to obtain selective products [13]. Despite so many research activities in this area, selectivity of the product, as well as the conversion efficiency have not been significantly improved. Hence, the research in this area should more focus on providing valuable hydrocarbons and facile separation of the products. For this purpose, extensive understanding of $\mathrm{CO}_{2}$ reduction mechanism is required; because this process comprises several dependent factors and parameters [14]. The photocatalyst composition, the reductant, and the solvent used in the reaction systemare important factors, which are affecting the products [15]. As observed in Equations (1) to (8), the alteration of the number of electrons and protons can give rise to different products. Correspondingly, to produce $\mathrm{CO}$, the reaction of $\mathrm{CO}_{2}$ with two protons and two electrons is required, while eight electrons and eight protons are required for producing $\mathrm{CH}_{4}$ [16]. Another challenge in $\mathrm{CO}_{2}$ photoreduction reaction is to enhance the efficiency of the reaction. Indeed, rapid recombination of electron/hole $\left(\overline{\mathrm{e}} / \mathrm{h}^{+}\right)$pairs is a key reason for decreased quantum efficiency. Consequently, fast recombination of these charges and poor light absorption cause low $\mathrm{CO}_{2}$ conversion efficiency, which limits the practical utilization of the photocatalysts for $\mathrm{CO}_{2}$ reduction $[17,18]$.

In particular, graphene, known as a single atomic layer of graphite arranged in six-membered rings of carbon atoms, is an expeditiously sparkling rising star on the horizon of materials science. The picturesque honey-comb-like and twodimensional (2D) $\mathrm{sp}^{2}$ hybridized graphene has become a hot spot on scientific research due to its extraordinary electrical, mechanical and thermal properties such as excellent mobility of charge carriers $\left(250000 \mathrm{~cm}^{2} / \mathrm{V} . \mathrm{s}\right)$, large surface area (calculated value $\left.=2630 \mathrm{~m}^{2} / \mathrm{g}\right)$, high thermal conductivity $(\sim 5000 \mathrm{~W} / \mathrm{m} . \mathrm{K})$, optical transparency and good chemical stability [19-21].

Up to now, different approaches have been developed to prepare individual or few layers of graphene sheets by exfoliating graphite flakes. The solution-phase isolation of graphene from graphite, which is the most common route, can be categorized in two different approaches. The first and most regularly used method is the modified Hummer's method using strong oxidizing agents to chemically exfoliate graphite to individual graphene oxide (GO) with abundance of oxygen moieties $[22,23]$. However, it is widely known that exfoliated GO exemplifies poor electronic conductivity resulting from the interruption of the $\pi$ system by substitution with a significant amount of defects (oxygen functional groups) [24]. Therefore, various reducing agents such as $\mathrm{NaBH} 4$ have been used to reduce $\mathrm{GO}$ for the restoration of $\mathrm{sp}^{2}$ hybridized network [25]. The second approach employs the ultrasonic energy to directly exfoliate graphite in a suitable solvent such as $\mathrm{N}, \mathrm{N}$-dimethylformamide (DMF) to yield solvent exfoliated graphene (SEG) [26]. Without employing the use of strong oxidizing agents, we developed a facile, low-cost and efficient approach by performing acid pre-treatment for the first time to introduce minimal oxygen-containing groups on the SEG (referred to as acid treated SEG (ATSEG)) for a better interfacial contact with composites. It is anticipated that the electrical mobility of the ATSEG-based nanocomposites with a longer electronic mean free path was enhanced as compared to that of GO-based nanocomposites [27].

Photoassisted $\mathrm{CO}_{2}$ reduction by $\mathrm{H}_{2}$ has been frequently reported using materials containing noble or critical metals, such as Pd, Ru and In in its composition [28-31]. For the sake of sustainability, it would be more convenient the use of abundant, non-critical first-raw transition metals in the process, Ni being an obvious candidate considering its availability and the fact that $\mathrm{Ni}$ supported on mixed silica alumina $\left(\mathrm{Ni} / \mathrm{SiO}_{2}-\mathrm{Al}_{2} \mathrm{O}_{3}\right)$ is a commercial catalyst for the thermal $\mathrm{CO}_{2}$ methanation. $\mathrm{CO}_{2}$ methanation is one of the few exothermic reactions involving $\mathrm{CO}_{2}$ as substrate and it can be conveniently carried out in a thermal process using $\mathrm{Ni} / \mathrm{SiO}_{2}-\mathrm{Al}_{2} \mathrm{O}_{3}$ as catalysts at temperatures above $400^{\circ} \mathrm{C}$ to reach high conversions and rates [32-36]. The advantage of the photoassisted reaction is that it can be performed in the range of temperatures in which the thermal process does not occur or gives only low $\mathrm{CO}_{2}$ conversions due to the low reaction rates. To shift equilibrium towards the products in an exothermic reaction, low reaction 
temperatures, but with adequate rates, are more favorable and this could be reached in the photoassisted process.

Continuing with this line of research, it is of much current interest to find other $\mathrm{Ni}$ containing materials that can exhibit even higher activity than $\mathrm{Ni} / \mathrm{SiO}_{2}-\mathrm{Al}_{2} \mathrm{O}_{3}$ for the photoassisted $\mathrm{CO}_{2}$ reduction by $\mathrm{H}_{2}$ to $\mathrm{CH}_{4}$ and to gain information about the mechanism of the photo-assisted process. In the present manuscript, it will be reported that $\mathrm{NiO} / \mathrm{Ni}$ nanoparticles (NPs) supported on few layers defective graphene (fl-G) is a suitable photocatalyst to promote the photoassisted $\mathrm{CO}_{2}$ reduction by $\mathrm{H}_{2}$ with specific rates and quantum yields of about $642 \mu \mathrm{mol} \cdot \mathrm{g} / \mathrm{Ni}$.h and $1.98 \%$, respectively. Graphene $(\mathrm{G})$ is a one-atom thick sheet constituted by $\mathrm{sp}^{2}$ carbons in hexagonal arrangement. Among the unique properties of $\mathrm{G}$ besides their high electric and thermal conductivity, others that important from the catalytic point of view are its high specific surface area (about $2500 \mathrm{~m}^{2} / \mathrm{g}$ and its strong interaction with supported metal NPs as consequence of the favorable overlap of the extended $\pi$ orbital of $\mathrm{G}$ with the $\mathrm{d}$ orbitals of the metal atoms $[37,38]$. In addition, $G$ and other 2D related materials have been successfully employed not only as support, but also as additive in catalysts for photocatalytic $\mathrm{CO}_{2}$ reduction [16,3942]. It is, therefore, of interest to demonstrate the general ability of graphenes to increase the photocatalytic activity of active components also for other photoassisted $\mathrm{CO}_{2}$ reductions. In the present manuscript a defective $G$ material obtained by pyrolysis from a natural polysaccharide that contains carbon vacancies, holes and residual oxygenated functional groups was used. Preparation of this type of defective $G$ from alginate has been already reported in the literature and fully characterization is available [43]. It appears that, as it has been well established in semiconducting photocatalysts [44-46]. the presence of graphene results in a remarkable enhancement of the efficiency of $\mathrm{Ni}$ to promote the photoassisted process.

Nickel oxide nanostructures were synthesized via solidstate thermal decomposition of $\mathrm{Ni}(\mathrm{acac})_{2}$ nanostructure as precursor that was prepared by sublimation method [47]. Furthermore, NiO/graphene nanocomposite was prepared by the pre-graphenization method that provides a large amount of sites for loading of $\mathrm{NiO}$. Besides, photocatalytic activity of the synthesized $\mathrm{NiO} /$ graphene nanocomposite was studied by degradation of methyl orange (MO) as a pollutant. The results of photocatalytic experiments showed that the degradation percentages of MO in existence of the as-prepared nanocomposite under UV and visible light irradiation were about $90.3 \%$ after $75 \mathrm{~min}$, and $78 \%$ after $180 \mathrm{~min}$, respectively, so this product can be used as an effective photocatalyst [48].

In this study, Photocatalysis for the production of solar fuels and particularly to perform $\mathrm{CO}_{2}$ reduction to $\mathrm{CH}_{4}$ with a sufficiently high efficiency depends to the presence of $\mathrm{H}_{2}$ and absence of $\mathrm{H}_{2} \mathrm{O}$ using graphene doped $\mathrm{Ni} / \mathrm{NiO}$ nanocomposite.

\section{Materials and Methods}

Materials and Procedures

Alginic acid Na salt from brown algae (Sigma) was pyrolized under $\mathrm{Ar}$ atmosphere at $900^{\circ} \mathrm{C}$ with a heating rate of $10^{\circ} \mathrm{C} /$ min for $2 \mathrm{~h}$ to obtain few-layers graphene (fl-G). Ni NPs were deposited by incipient wetness impregnation, adding dropwise a $10 \mathrm{ml} \mathrm{Ni}$ (II) chloride hexahydrate solution over preformed fl-G powders under constant stirring. After this time, the $\mathrm{Ni}(\mathrm{x})-\mathrm{G}$ (x: wt.\% Ni) photocatalyst was filtered and washed with mili $\mathrm{Q}$ water and acetone until the complete removal of chloride. The solid catalysts were, then, dried overnight in an oven at $80^{\circ} \mathrm{C}$. The fl-G powders were reduced under $\mathrm{H} 2$ flow $(100 \mathrm{ml} / \mathrm{min})$ at $500 \mathrm{oC}$ for $2 \mathrm{~h}$ with a heating rate of $10^{\circ} \mathrm{C} /$ min. The resulting material was dried in a vacuum desiccator at $110 \mathrm{oC}$ to remove the remaining $\mathrm{H} 2 \mathrm{O}$ and stored under ambient atmosphere before its use as photocatalyst. The amount of Ni present in the samples was determined by inductively coupled plasma-optical emission spectrometry by immersing the catalysts into aqua regia at room temperature for $12 \mathrm{~h}$ and analyzing the Ni content of the resulting solution.

\section{Characterization}

Powder XRD (X-ray diffraction analysis) patterns were recorded on a Shimadzu XRD-7000 diffractometer using $\mathrm{Cu}$ $\mathrm{K} \alpha$ radiation $(\lambda=1.5418 \AA, 40 \mathrm{kV}, 40 \mathrm{~mA})$ at a scanning speed of $1^{\circ} / \mathrm{min}$ in the $10-80^{\circ} 2 \theta$ range. Raman spectrum was collected with a Horiba Jobin Yvon-Labram HR UV-Visible NIR (200-1600 nm) Raman microscope spectrometer, using a laser with the wavelength of $512 \mathrm{~nm}$. The spectrum was collected from 10 scans at a resolution of $2 / \mathrm{cm}$.

X-Ray Photo Spectroscopy (XPS) spectra were measured on a SPECS spectrometer equipped with a Phoibos 150 9MCD detector using a non-monochromatic X-ray source (Al and $\mathrm{Mg}$ ) operating at $200 \mathrm{~W}$. The samples were evacuated in the prechamber of the spectrometer at $1 \times 10^{-9}$ mbar. The measured intensity ratios of the components were obtained from the area of the corresponding peaks after nonlinear Shirley-type background subtraction and corrected by the transition function of the spectrometer.

Transmission electron microscopy (TEM) images were recorded in a JEOL JEM $2100 \mathrm{~F}$ under $200 \mathrm{kV}$ accelerating voltage. Samples were prepared by applying one drop of the suspended material in ethanol onto a carbon-coated copper TEM grid, and allowing them to dry at room temperature.

Diffuse reflectance UV-Vis spectra (DRS) in the range of 200$800 \mathrm{~nm}$ were recorded on a Cary 5000 spectrophotometer from Varian.

\section{Photocatalytic tests}

A photoreactor $(51 \mathrm{ml})$ with a quartz window and a Ni alloy thermocouple was load with $\mathrm{Ni}(\mathrm{x})-\mathrm{G}$ photocatalyst. $\mathrm{H}_{2}$ and $\mathrm{CO}_{2}$ were introduced in stoichiometric amounts up to achieve a final pressure of 1.3 bar. The photoreactor was heated at different temperatures prior irradiation by means of a heating 
mantle equipped with thermocouple and controller, and when the desired temperature was stabilized the photocatalyst was irradiated with a UV-Vis light from a $300 \mathrm{~W}$ Xe lamp. Note that the time required before temperature equilibration can be about $30 \mathrm{~min}$. At that moment the lamp is switched on and this is the initial time of the experiments. No change in the gas phase composition was observed at initial reaction time. The $\mathrm{CH} 4$ formation was followed by direct measurement of the reactor gases with an Agilent 490 MicroGC having two channels both with TC detectors and $\mathrm{Ar}$ as carrier gas. One channel has MolSieve 5A column and analyses $\mathrm{H}_{2}, \mathrm{O}_{2}, \mathrm{~N}_{2}$ and $\mathrm{CO}$. The capability of our Micro GC apparatus to detect $\mathrm{CO}$ using $\mathrm{Ar}$ as carrier gas has been tested using Abell Linder ${ }^{\mathbb{R}}$ steel cylinders containing certified $\mathrm{N}_{2}$ : $\mathrm{CO}$ mixtures at different concentrations (20, 10 and 5 vol.\%) (Fig. 1). The second channel has a Pore Plot Q column and analyses $\mathrm{CO}_{2}, \mathrm{CH}_{4}$ and up to $\mathrm{C}_{4}$ hydrocarbons. Quantification of the percentage of each gas was based on prior calibration of the system injecting mixtures with known percentage of gases.

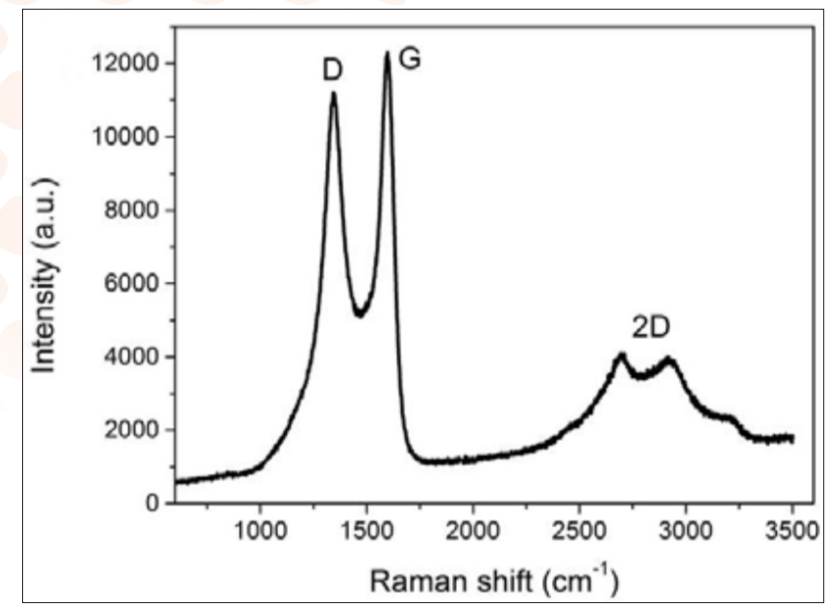

(a)

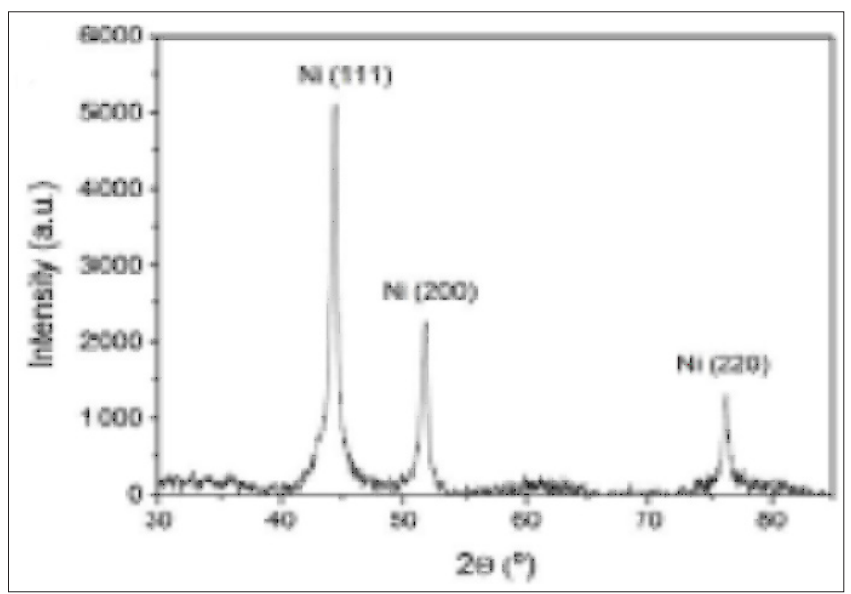

(b)

Figure 1: (a) Raman spectrum of $f l-\mathrm{G}$ from alginate pyrolysis and subsequent exfoliation recorded upon $512 \mathrm{~nm}$ laser excitation (b) XRD pattern of $\mathrm{Ni}(23)-\mathrm{G}$ photocatalyst.

\section{Preparation of $\mathrm{NiO}$ nanoparticles}

In this synthesis, $\mathrm{NiO}$ nanoparticles were synthesized by the thermal decomposition of $\mathrm{Ni}$ (acac) 2 nanostructures as a precursor that was prepared via sublimation method. 0.1 $\mathrm{g}$ of the precursor was placed in a crucible and was heated up to $500^{\circ} \mathrm{C}$ for $120 \mathrm{~min}$. Then, the precipitation was cooled to room temperature and the final product was characterized by XRD, Scanning Electron Microscopy (SEM), TEM, Energy dispersive X-ray spectroscopy (EDS) and magnetic properties of the product was investigated by Vibrating sample magnetometer (VSM).

\section{Synthesis of GNS from GO}

In this study, the used GO was prepared by a modified Hummers method from natural graphite and reduced through the described method in previous work $[49,50]$.

\section{Preparation of $\mathrm{NiO} / \mathrm{graphene}$ nanocomposite}

The NiO/graphene nanocomposite was synthesized via a pregraphenization technique. Briefly, $0.1 \mathrm{~g}$ from obtained NiO NPs $(0.4 \mathrm{mmol})$ was added to the black suspension of graphene $(0.5$ $\mathrm{mg} / \mathrm{ml}$ ) and magnetically stirred for $20 \mathrm{~min}$ at $90^{\circ} \mathrm{C}$. Finally, the above mixture was put in a household microwave oven (Haier, $2450 \mathrm{MHz}, 750 \mathrm{~W}$ ) for $10 \mathrm{~min}$ and then it was cooled to room temperature, naturally. Subsequently, the black precipitation was filtered, washed with distilled $\mathrm{H}_{2} \mathrm{O}$ and absolute alcohol, and dried at $100^{\circ} \mathrm{C}$ for $12 \mathrm{~h}$ in a vacuum oven. The resulted black powder was collected for the following characterization. The product was characterized by XRD, SEM and UV-vis spectroscopy.

\section{Photocatalytic $\mathrm{CO}_{2}$ Conversion}

In the photocatalytic $\mathrm{CO}_{2}$ conversion experiment, an empty photoreactor (stainless steel; $\mathrm{V}=15.4 \mathrm{~cm}^{3}$ ) was purged with $\mathrm{CO}_{2}$ gas $(1000 \mathrm{mg} / \mathrm{l}$ in $\mathrm{He})$ and vacuum simultaneously to remove any air or other impurities before and after the loading of the photocatalyst [51]. The photocatalyst (50 mg) was loaded into the photoreactor; moist $\mathrm{CO}_{2}$ gas $(1000 \mathrm{mg} / \mathrm{l}$ in $\mathrm{He})$ was passed through a water bubbler, which then enters the photoreactor. The photocatalyst-loaded photoreactor, filled with a mixture of $\mathrm{CO}_{2}$ and $\mathrm{H}_{2} \mathrm{O}$ vapors mixture, was then illuminated by a $100 \mathrm{~W}$ Xenon solar simulator (Oriel, LCS-100) with an AM1.5 filter for $1 \mathrm{~h}$, and the reaction products $(500 \mu \mathrm{l})$ were analyzed using a Shimadzu GC-2014 gas chromatograph (Restek Rt-Q Bond column, ID $=0.53 \mathrm{~mm}$, and length $=30 \mathrm{~m}$ ) equipped with flame ionization (FID) and thermal conductivity (TCD) detectors. The hournormalized photocatalytic $\mathrm{CH} 4$ evolution rate is calculated using Eq. 9.

Rate of $\mathrm{CH}_{4}$ evolution $=\frac{\text { amount of } \mathrm{CH}_{4} \text { produced }(\mathrm{mg} / \mathrm{l})}{\text { amount of photocatalyst used }(\mathrm{g})}$

Five cycles of $\mathrm{CO}_{2}$ photoreduction were performed to test the stability of the same sample; after every test, the photoreactor was purged with Ar gas and vacuum, then re-filled with $\mathrm{CO}_{2}$ gas $(1000 \mathrm{mg} / \mathrm{l}$ in $\mathrm{He})$, followed by a $1 \mathrm{~h}$ illumination for the next testing cycle.

\section{Results and Discussions}

\section{Photocatalyst preparation and characterization}

NiO-Ni NPs supported on $f l-\mathrm{G}$ with different Ni content were prepared adding different amounts of 4 hydrated $\mathrm{NiCl}_{2}$ to $f l-\mathrm{G}$ dispersions, followed by subsequent thermal reduction of $\mathrm{Ni}^{+2}$ 
by $\mathrm{H}_{2}$ atmosphere at $500^{\circ} \mathrm{C}$ for $2 \mathrm{~h}$. After chemical reductions, the resulting samples were stored under ambient for at least one day before being uses as photocatalyst. This exposure to the ambient can cause some oxidation of the $\mathrm{Ni}$, as it will be discussed below. The Ni content of each sample has been confirmed by ICP-OES elemental analysis. The different samples under study and their respective Ni contents (wt.\%) are summarized in Table 1.

\begin{tabular}{|c|c|c|c|c|}
\hline Samples & $\mathrm{Ni}(\mathrm{wt} \%)^{\mathrm{a}}$ & Size (nm) & \begin{tabular}{|l|} 
T o t a 1 \\
Catalyst \\
a moun t \\
$(\mathrm{mg})$
\end{tabular} & $\begin{array}{l}\mathrm{CH}_{4}(\mu \mathrm{mol} / \\
\text { gNi.h }\end{array}$ \\
\hline $\mathrm{fl}-\mathrm{G}^{\mathrm{a}}$ & - & - & 26.12 & 0 \\
\hline $\mathrm{Ni}(6)-\mathrm{G}$ & 6.61 & - & 20.17 & 0 \\
\hline $\mathrm{Ni}(14)-\mathrm{G}$ & 14.42 & $8.0 \pm 2.0$ & 25.40 & 329.01 \\
\hline $\mathrm{Ni}(23)-\mathrm{G}$ & 23.02 & $8.5 \pm 3.50$ & 40.10 & 642.68 \\
\hline $\mathrm{Ni}(23)-\mathrm{G}^{\mathrm{b}}$ & 23.02 & $8.5 \pm 3.52$ & 39.60 & 0 \\
\hline $\mathrm{Ni}(23)-\mathrm{G}^{\mathrm{c}}$ & 23.02 & $8.5 \pm 3.56$ & 25.20 & 0 \\
\hline $\mathrm{Ni}(26)-\mathrm{G}$ & 26.10 & $13.7 \pm 6.0$ & 37.30 & 303.09 \\
\hline $\begin{array}{l}\mathrm{Ni}-\mathrm{Al}_{2} \mathrm{O}_{3} / \\
\mathrm{SiO}_{2}\end{array}$ & 65.30 & $6.22 \pm 1.14^{\mathrm{d}}$ & 14.40 & 358.50 \\
\hline $\mathrm{NiO}$ & - & $<50$ & 12.73 & 31.12 \\
\hline NiO-fl-G & 23.01 & & 25.41 & 69.86 \\
\hline $\mathrm{Ni}(23)-\mathrm{G}^{\mathrm{f}}$ & 23.06 & $8.5 \pm 3.50$ & 25.54 & 0 \\
\hline
\end{tabular}

a) The difference in weight corresponds to the percentage of graphene;

b) Room temperature;

c) Dark conditions;

d) Photocatalysts pre-activated under $\mathrm{H} 2$ atmosphere at $200 \mathrm{oC}$, at $4 \mathrm{~h}$ and subsequent reaction at room temperature under light illumination.

Table 1: The Ni content in the $\mathrm{NiO} / \mathrm{Ni}-\mathrm{G}$ samples with $\mathrm{Ni}$ average particle size and total catalyst amount. Experimental conditions: at $200^{\circ} \mathrm{C}$, at $2240 \mathrm{~W} / \mathrm{m}^{2}$, at $300 \mathrm{~W}$ Xe lamp irradiation, at $\mathrm{PH} 2=1.05$ bar and at $\mathrm{PCO}_{2}=0.25$ bar, respectively.

Raman spectroscopy was employed to characterize the defective fl-G used as support. The Raman spectrum revealed the typical 2D $(2700 / \mathrm{cm}), \mathrm{G}(1580 / \mathrm{cm})$ and $\mathrm{D}(1350 / \mathrm{cm})$ bands characteristic to the defective $G$ obtained from the pyrolysis of alginate (Fig. 1a). The defects correspond to carbon vacancies and holes generated by evolution of $\mathrm{CO}_{2}$ and $\mathrm{CO}$ during the pyrolysis and to the presence of residual oxygen (about $7 \mathrm{wt} . \%$ ) remaining from the composition of the polysaccharide precursor after pyrolysis. XRD pattern of the $\mathrm{Ni}(23)-\mathrm{G}$ photocatalyst revealed that the $\mathrm{NiO} / \mathrm{Ni} \mathrm{NPs}$ were highly crystalline and mainly constituted by Ni metal (Fig. 1b). Diffraction peaks corresponding to $\mathrm{NiO}, \mathrm{Ni}(\mathrm{OH})_{2}$ or $\mathrm{Ni}_{2} \mathrm{O}_{3}$ were undetectable in the diffractogram as can be appreciated in Fig. 1b.

SEM and TEM images of $\mathrm{NiO}$

The SEM image of the as-synthesized NiO is shown in Fig. 2a. In this image, are shown the particles with size about 50 $\mathrm{nm}$. The TEM and Selected area electron diffraction (SAED) images of the NiO NPs are illustrated in Fig. $2 b$ and Fig. 2c, respectively. Uniform NiO NPs with size about $20 \mathrm{~nm}$ can be seen in Fig. 2b. The SEAD pattern indicates that the NiO NPs are polycrystalline. They are further indexed as the cubic phase (Fig. 2c). The HRTEM image of the NiO NPs is shown in Fig. 2d. The interplanar spacing is about $0.24 \mathrm{~nm}$, which corresponds to the (llll) plane of the cubic crystalline NiO. Therefore, the HRTEM image further verifies the cubic nature of the synthesized NiO NPs.

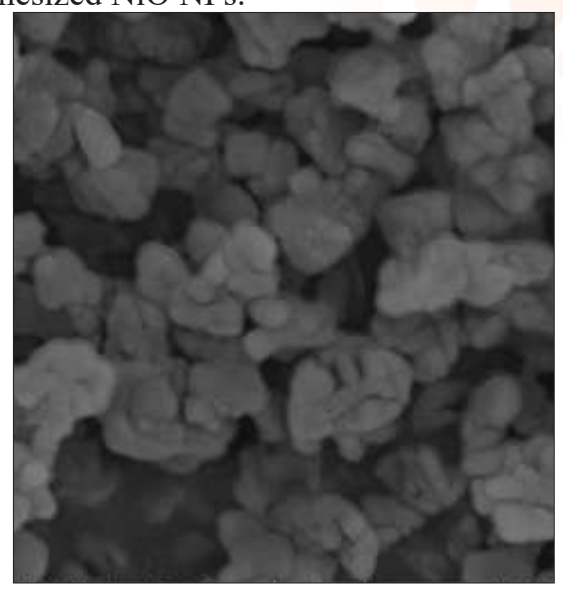

(a)

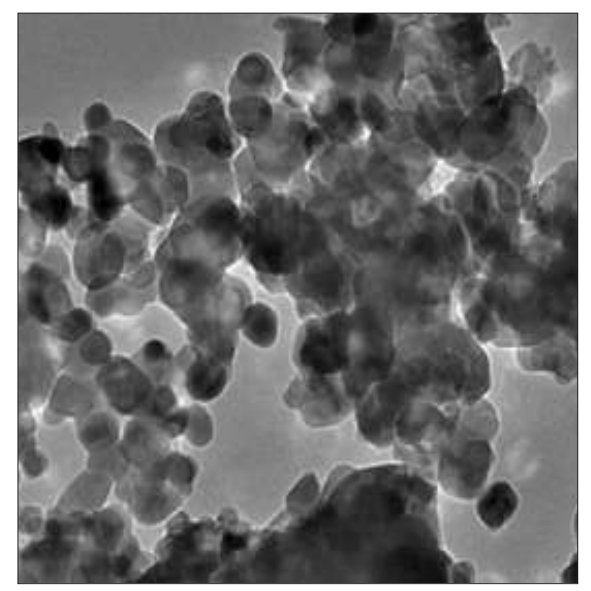

(b)

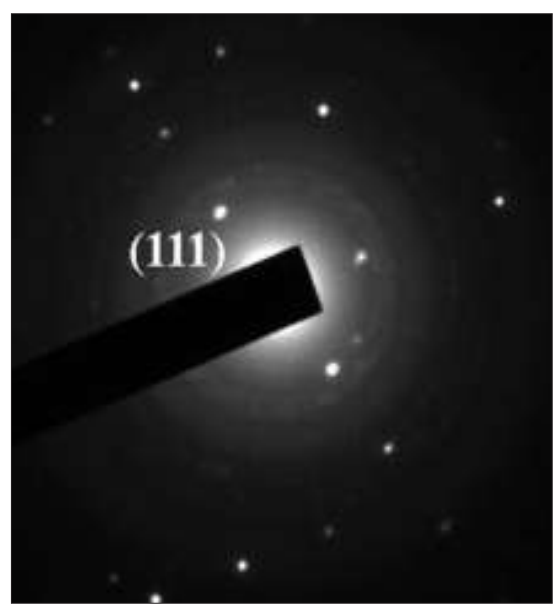

(c) 


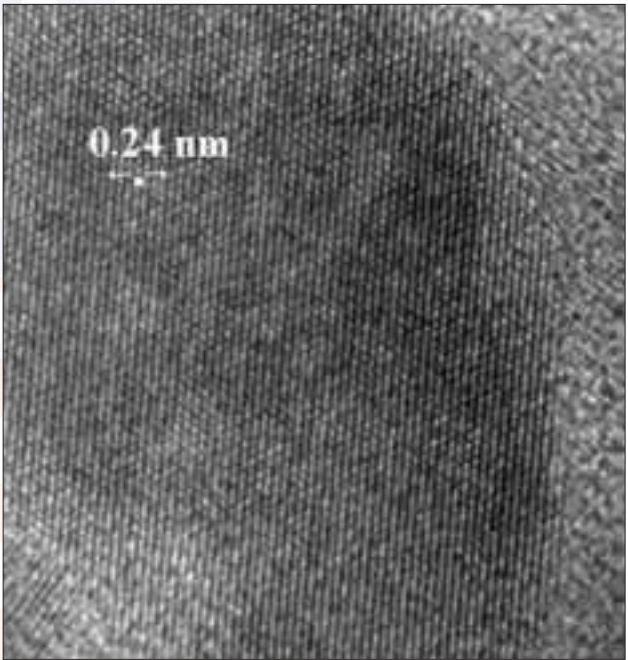

(d)

Figure 2: (a) SEM image of $\mathrm{NiO}$ and (b) TEM image of $\mathrm{NiO}$, (c) SAED pattern of $\mathrm{NiO}$ and (d) HRTEM image of $\mathrm{NiO}$.

XRD pattern and EDS spectrum of $\mathrm{NiO}$

XRD pattern of NiO NPs is shown in Fig. 3a. It is indexed as a püre cubic structure with according to the literature value (JCPDS card no. 78-0429, Space group: Fm-3m, a = $\mathrm{b}=\mathrm{c}=4.1771)$. The crystallite size was estimated using the Scherrer equation is about $30 \mathrm{~nm}$ [52]. Fig. $3 b$ shows the EDS microanalysis of the obtained NiO NPs. The Ni and $\mathrm{O}$ elements in this spectrum were characterized and there were no peaks, so, the purity of the synthesized NiO NPs was confirmed.

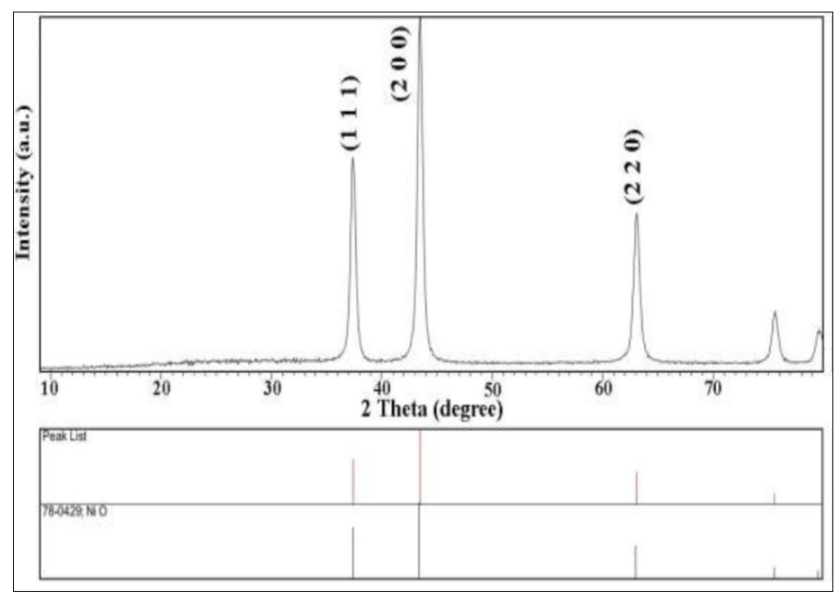

(a)

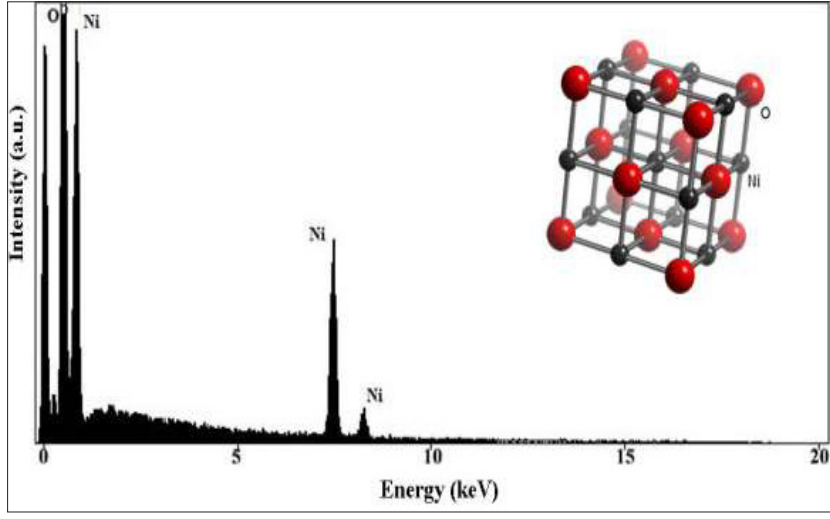

(b)

Figure 3: (a) XRD pattern and (b) EDS spectrum of the obtained NiO.

\section{SEM image and XRD pattern of NiO/graphene} nanocomposite

Fig. 4a and Fig. 4b show the low and high magnification FESEM images of the NiO/graphene nanocomposite. From the high magnification image (Fig. 4b), it is clear that the product consists sheet-like structures that NiO NPs (20-30 nm) put on them. The purity of the $\mathrm{NiO}$ /graphene nanocomposite was confirmed by X-ray diffraction (XRD) pattern. The diffraction peaks (lll 111$),\left(\begin{array}{lll}2 & 0 & 0\end{array}\right),\left(\begin{array}{lll}2 & 2 & 0\end{array}\right)$, and (3 111$)$ in Fig. 4c can be indexed to the cubic phase $\mathrm{NiO}$ with space group of $\mathrm{Fm} / 3 \mathrm{~m}$ (JCPDS No. 78-0429) and the broad peak located at 26.5 ( 00 2) corresponds to layered GNS [49]. Presence of $\mathrm{NiO}$ crystals in the graphene-based composite was confirmed by the other diffraction peaks in this pattern (Fig. 4c), this result was supported by SEM image and TEM image (Fig. 2a and 2b).

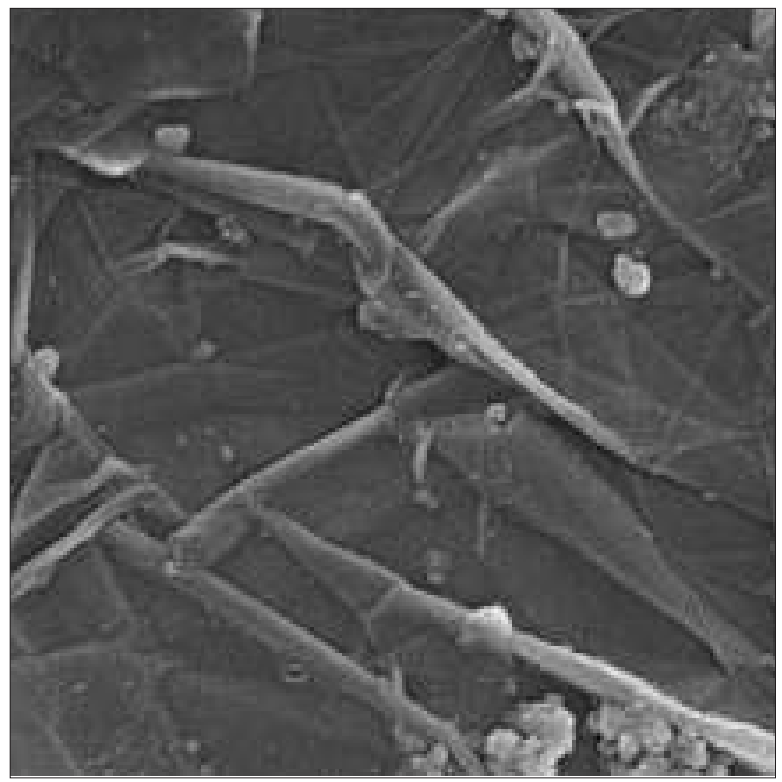

(a) 


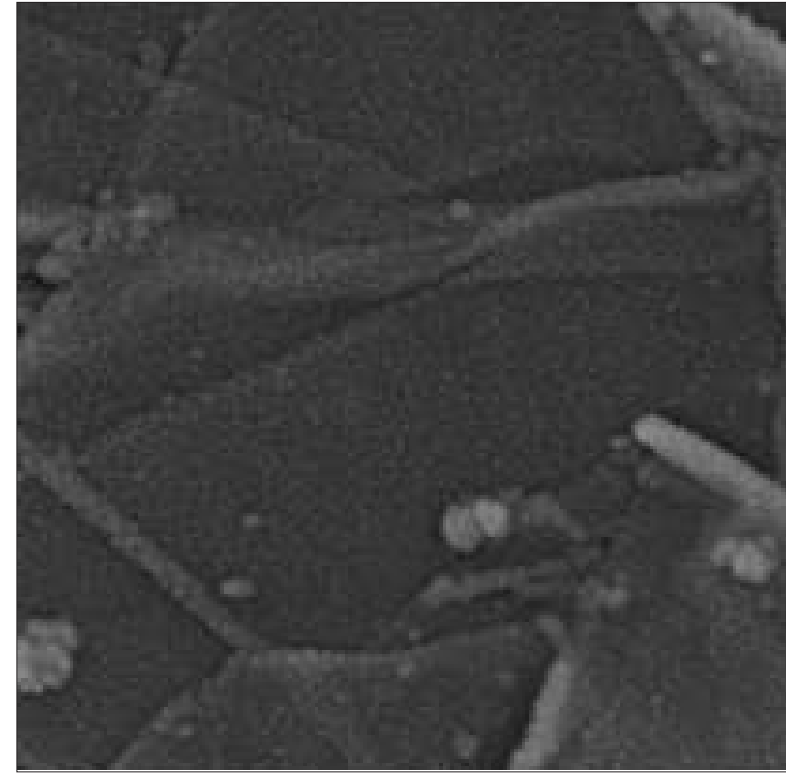

(b)

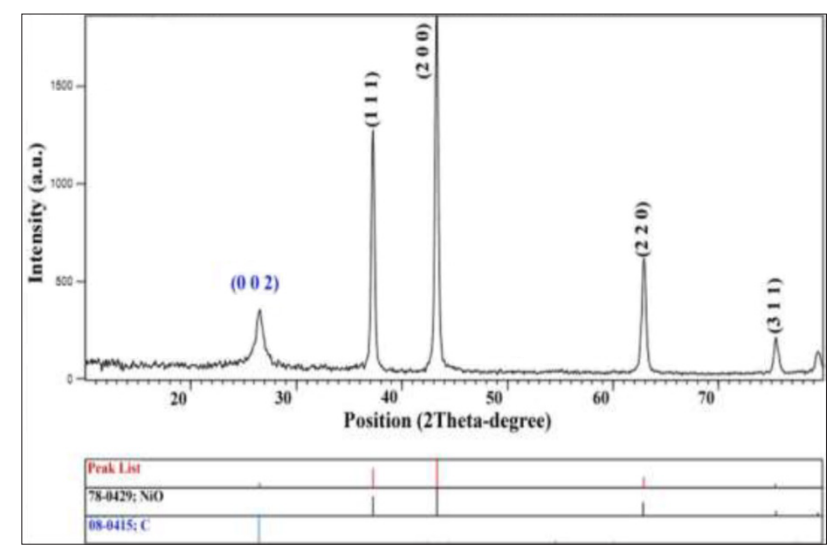

(c)

Figure 4: (a) Low magnification FESEM image, (b) high magnification FESEM image and (c) XRD of the $\mathrm{NiO}$ / graphene nanocomposite.

The presence of NiO/Ni NPs on the fl-G sheets was observed by HRTEM and confirmed by FESEM, EDS and elemental mapping (Fig. 5). Fig. 5a corresponds to a representative HRTEM image of $\mathrm{NiO} / \mathrm{Ni}-\mathrm{G}$ showing that $\mathrm{NiO} / \mathrm{Ni} \mathrm{NPs}$ are homogeneously distributed on fl-G sheets. For comparison, an image of $f-\mathrm{G}$ sample, prior to Ni deposition, has been also presented as Fig. 5b as well as in Fig. 6. The supported $\mathrm{NiO} /$ Ni NPs have a round morphology, as can be observed in the magnified image presented in Fig. 5c, with diameters typically smaller than $10 \mathrm{~nm}$, increasing average particle size with the Ni loading on the $G$ sheet. The histogram corresponding to the particle size distribution for the $\mathrm{Ni}(23)-\mathrm{G}$ is presented in Fig. $5 \mathrm{~d}$. From the measurement of a statistically relevant number of Ni NPs and average particle size of $8.5 \pm 3.5 \mathrm{~nm}$ was estimated for this sample in spite of the relatively high Ni loading. Highresolution TEM allowed to measure $0.18 \mathrm{~nm}$ for particle lattice fringe that corresponds to the interplanar distance of the 200 facets of fcc Ni metal particles thus, confirming that the particles are mainly constituted by $\mathrm{Ni}^{0}[53]$.

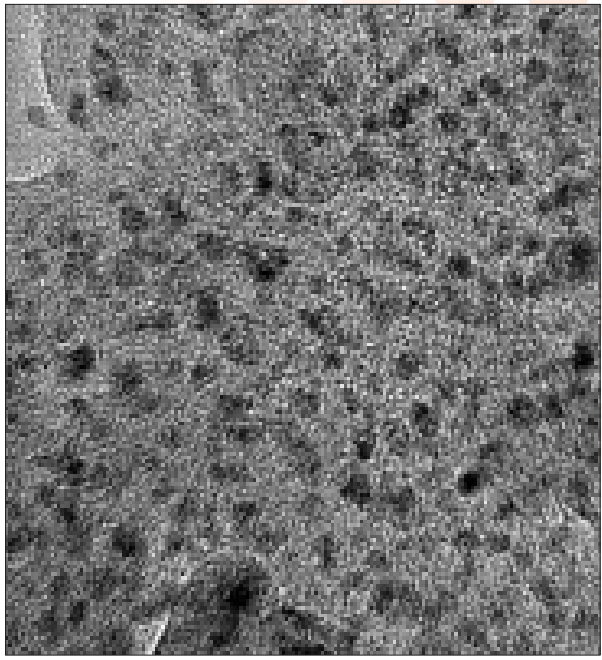

(a)

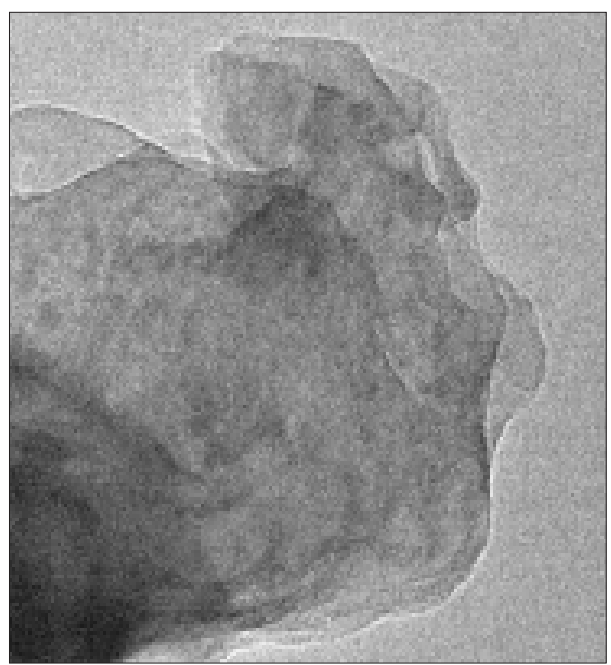

(b)

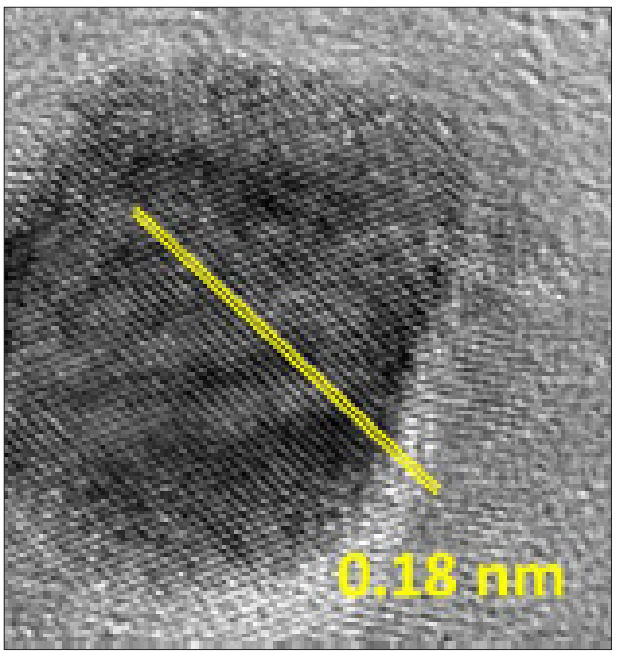

(c) 


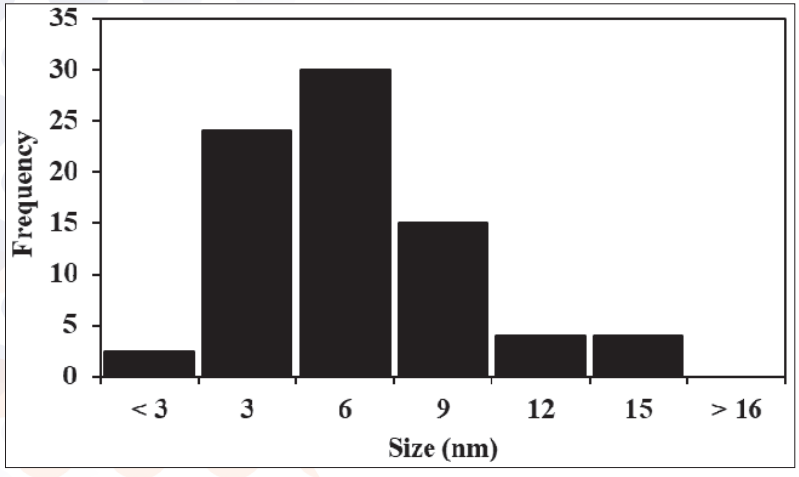

(d)

Figure 5: HRTEM images of (a) Ni(23)-G photocatalyst, (b) fl-G; (c) the $\mathrm{NiO} / \mathrm{Ni} \mathrm{NP}$ and (d) the particle size distribution.

High-resolution XPS peaks of Ni $2 p$ and their corresponding best deconvolution to the different $\mathrm{Ni}$ oxidation states are presented in Fig. 6. The Ni 2p3/2 peak shows the presence of two components centered at $853.6 \mathrm{eV}$ and $856.3 \mathrm{eV}$ that can be attributed to $\mathrm{Ni}^{0}$ and $\mathrm{Ni}^{+2}$, respectively. These binding energies are shifted to higher values compared to those reported in the literature for $\mathrm{Ni}^{0}$ and $\mathrm{Ni}^{+2}$ at 852 and $854 \mathrm{eV}$, respectively, indicating the occurrence of charge transfer from NiO/Ni NPs as electron donor to G. Previously, a shift to higher binding energy values of $2 \mathrm{eV}$ was also observed for Ni NPs adsorbed on $\mathrm{G}$ [54]. Moreover, in the present case, the $\mathrm{Ni0}$ is as a minor component of the experimental XPS Ni 2p3/2 peak. Therefore, in addition to $\mathrm{Ni}^{0}$ as the predominant phase characterized by XRD, XPS shows the presence of $\mathrm{NiO}$ determined by the prominent satellites observed in the $\mathrm{Ni} 2 \mathrm{p} 3 / 2$ and $\mathrm{Ni} 2 \mathrm{p} 1 / 2$ peaks. To reconcile both observations, it is worth reminding that while XRD probes the whole sample, XPS only provides information of the outermost nanometers of the metal NPs that are more prone to undergo spontaneous oxidation by exposure to the atmosphere. In addition, XRD is useful characterize crystalline $\mathrm{NiO}$ and the presence of $\mathrm{NiO}$ as amorphous material due to its thin dimensions would be undetectable by XRD. Therefore, XPS provides two important pieces of information the presence of $\mathrm{NiO}$ on the NPs and the charge transfer from $\mathrm{NiO} / \mathrm{Ni} \mathrm{NPs}$ to $f-\mathrm{G}$, implying a notable interaction between them. It should be reminded that even though the preparation of the Ni-G samples was made by $\mathrm{H}_{2}$ reduction of $\mathrm{Ni}^{+2}-\mathrm{G}$ at $500^{\circ} \mathrm{C}$ for $2 \mathrm{~h}$, the samples were stored under ambient conditions and this should lead to a fast passivation of the surface of the $\mathrm{Ni}$ NPs with the formation of some $\mathrm{NiO}$ overlayers.

The C 1s XPS peak (Fig. 6) shows a major component centered at $284.5 \mathrm{eV}$ corresponding to graphenic $\mathrm{sp}^{2} \mathrm{C}$, as well as other contributions at 285.5, 286.6 and $289.2 \mathrm{eV}$ corresponding to $\mathrm{C}$ atoms bonded to $\mathrm{O}$ atoms corresponding to ketones, epoxides and carbonyls groups, respectively. The XPS peak of O 1s (Fig. 6) can be adequately deconvoluted in two main components corresponding to oxygen atoms bonded to $\mathrm{C}$ through single or double bonds. The presence of a component at $529.4 \mathrm{eV}$ corresponding to $\mathrm{NiO}$ was also observed, although as a minor component [55]. However, the component at $531.1 \mathrm{eV}$ related to $\mathrm{Ni}(\mathrm{OH})_{2}$ could not be identified, confirming $\mathrm{NiO}$ as the main oxide component in the Ni $2 \mathrm{p} 3 / 2$ that should form a thin coating on the major metallic Ni NPs [55].

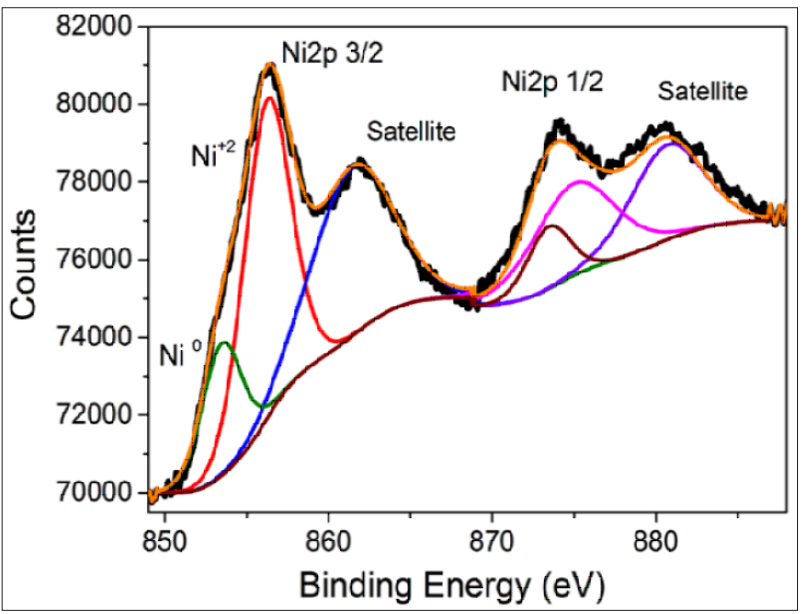

Figure 6: Experimental XPS Ni 2p peaks for the Ni(23)-G sample.

\section{VSM analyses}

Magnetization curves of $\mathrm{NiO} \mathrm{NPs}$ and $\mathrm{NiO}$ /graphene nanocomposite at room temperature are shown in Fig. $7 \mathrm{a}$ and Fig. 7b, respectively. $\mathrm{NiO} \mathrm{NPs}$ and $\mathrm{NiO} /$ graphene nanocomposite depict a pseudo-single domain and superparamagnetic behavior, respectively, although bulk NiO has now been antiferromagnetic [56]. Pseudo-single domain behavior of $\mathrm{NiO}$ and superparamagnetism characteristic of $\mathrm{NiO} /$ graphene nanocomposite is confirmed by two signs: The ' $\mathrm{S}$ '-shaped curve and low coercivity $(\mathrm{Hc}=214.2$ Oe for $\mathrm{NiO}$ $\mathrm{NPs}$ ), the saturation magnetization, $\mathrm{Ms}=1 \mathrm{emu} / \mathrm{g}$ is reached at an applied field of 6000 Oe [57].

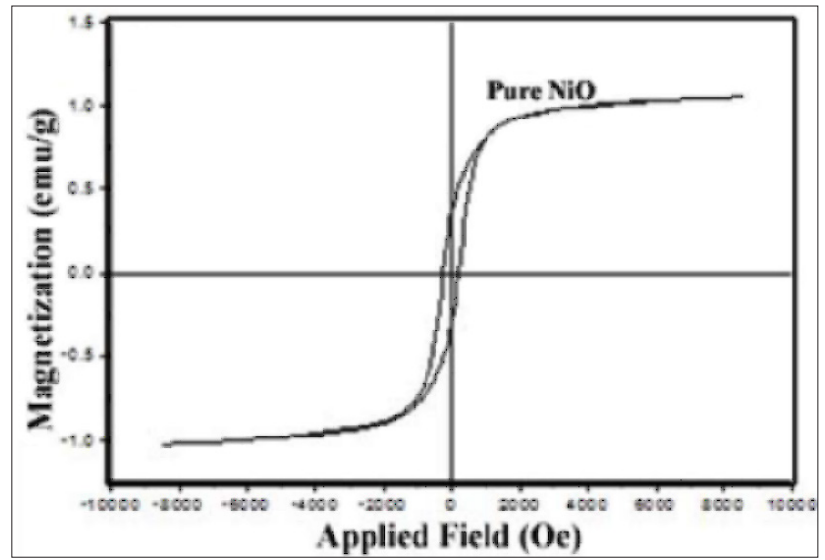

(a) 


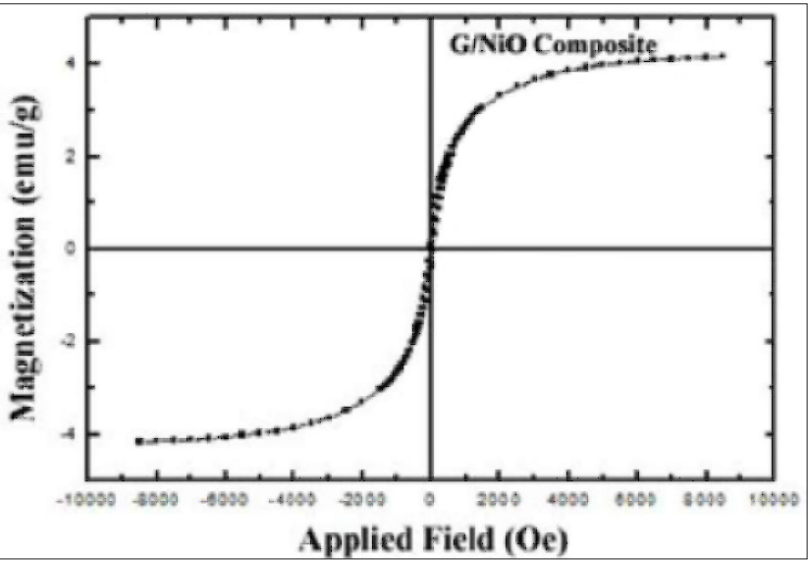

(b)

Figure 7: Magnetization versus applied magnetic field at room temperature for (a) pure $\mathrm{NiO}$ nanostructures and (b) $\mathrm{NiO} /$ graphene nanocomposite.

Superparamagnetism occurs in NPs, which are single-domain, i.e. composed of a single magnetic domain and this is possible when their diameter is below $50 \mathrm{~nm}$, depending on the materials. When an external magnetic field is applied to an assembly of superparamagnetic NPs, their magnetic moments tend to align along the applied field, leading to a net magnetization. The magnetization curve of the assembly, i.e. the magnetization as a function of the applied field, is a reversible S-shaped increasing function [58]. This change in magnetic property of bulk and NiO NPs and NiO/graphene nanocomposite can be ascribed to finite size effect and unique structure of graphene. With decreasing size of magnetic particles: 1) finite size effect becomes more important and 2) the presence of defects, lattice expansion, broken nature of exchange bonds, and fluctuations in the number of atomic neighbors cause disorder of surface spin and frustration [59].

Recently, extensive studies have been reported about particle size dependent magnetic properties and finite size versus surface effects on magnetic properties of $\mathrm{NiO}$ systems have been studied and these investigations show that the strong interplay between finite size effects, surface and interface effects, and defects or oxygen vacancies cause the magnetic properties in $\mathrm{NiO}$ become very complex [60-63].

\section{UV-vis absorption spectra}

The diffuse reflectance UV-Vis spectra of Ni(23)-G and G samples are shown in Fig. 8a and Fig. 8b. As can be observed there, the only contribution of the Ni NPs in the NiO/Ni-G photocatalyst absorption is in the UV region, below $350 \mathrm{~nm}$ $[64,65]$. NiO should present a prominent band centered at $500 \mathrm{~nm}$, however, in the present case this band could not be detected, thus confirming Ni metal as the principal oxidation state in the NPs as indicated by XRD and that the layer of NiO, detectable only by XPS, has to be thin.

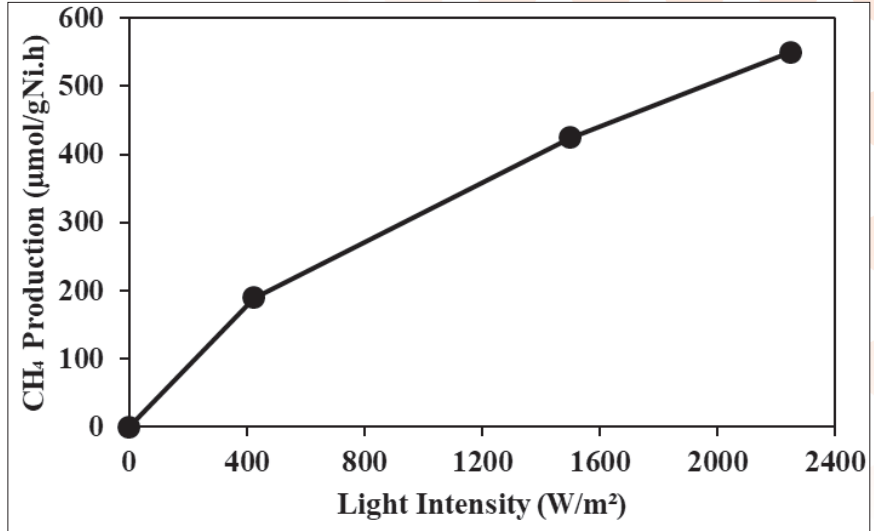

(a)

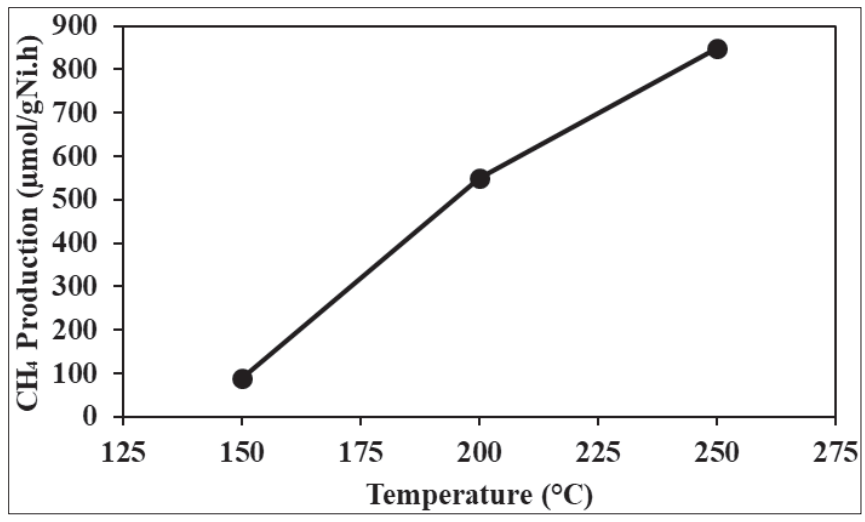

(b)

Figure 8: Specific $\mathrm{CH}_{4}$ production rate of $\mathrm{Ni}(23)-\mathrm{G}$ photocatalyst as a function of (a) the light intensity and (b) temperature. Experimental conditions: at total catalyst amount in the light intensity: $25 \mathrm{mg}$, at total catalyst amount in temperature experiments: $36 \mathrm{mg}$, at $200^{\circ} \mathrm{C}$, at $2240 \mathrm{~W} / \mathrm{m}^{2}$, at $\mathrm{PH}_{2}=1.05$ bar and at $\mathrm{PCO}_{2}=0.25$ bar, respectively.

In Fig. 8, the specific $\mathrm{CH}_{4}$ production initial rate is clearly dependent of the irradiation power, confirming that, under the present conditions, the $\mathrm{CO}_{2}$ methanation is a photoassisted process. The apparent quantum yield at $200^{\circ} \mathrm{C}$ in the photocatalytic $\mathrm{CO}_{2}$ reduction using the $\mathrm{Ni}(23)-\mathrm{G}$ photocatalyst was estimated of $1.98 \%$. On the other hand, the specific $\mathrm{CH}_{4}$ production initial rate at constant illumination varied also as a function of the reaction temperature. As commented before, reactions performed at room temperature resulted in negligible $\mathrm{CH}_{4}$ production initial rate (see Table 1). Heating the photoreactor at $150^{\circ} \mathrm{C}$ resulted in $\mathrm{CH}_{4}$ evolution rates below $100 \mu \mathrm{mol} / \mathrm{gNi}$.h. However, temperature of $250^{\circ} \mathrm{C}$ produced $\mathrm{CH}_{4}$ at a specific rate of $850 \mu \mathrm{mol} / \mathrm{gNi}$.h. The dependency of the specific $\mathrm{CH} 4$ production rate with the temperature of the system allows us to calculate an apparent activation energy of $38.6 \mathrm{~kJ} / \mathrm{mol}$ for the process (Fig. 9a and Fig. 9b). 


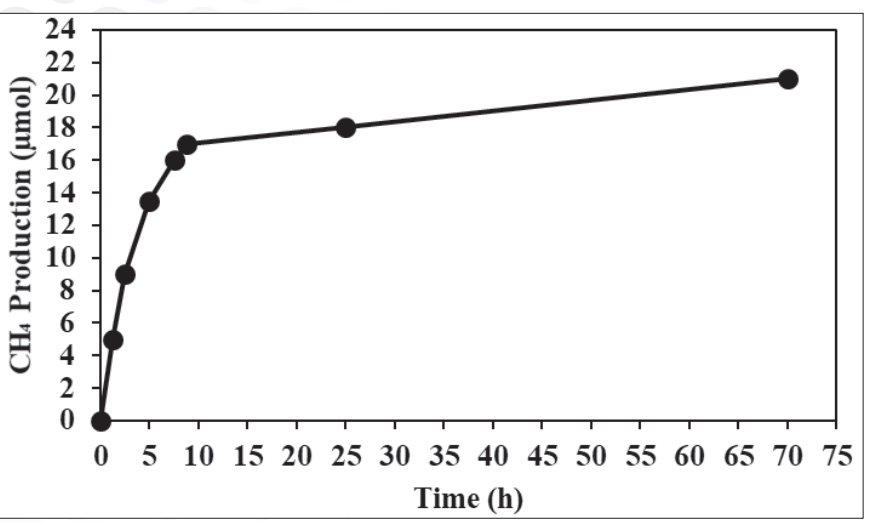

(a)

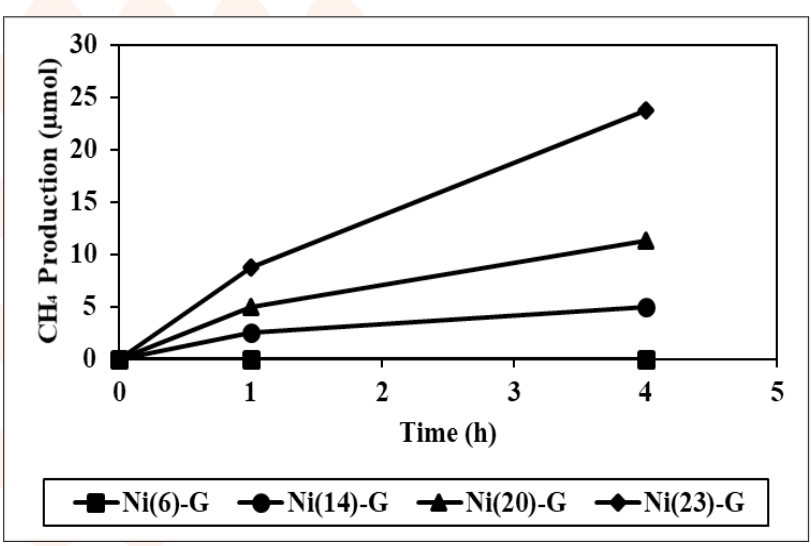

(b)

Figure 9: (a) $\mathrm{CH}_{4}$ production versus photocatalysis time and (b) $\mathrm{CH}_{4}$ evolution using the $\mathrm{Ni}(23)-\mathrm{G}$ photocatalyst. Experimental conditions: at $200^{\circ} \mathrm{C}$, at $2240 \mathrm{~W} / \mathrm{m}^{2}$, at $34.7 \mathrm{mg} \mathrm{Ni}(23)-\mathrm{G}$, at $\mathrm{PH} 2=1.05$ bar and at $\mathrm{PCO}_{2}=0.25$ bar, respectively.

To gain understanding on the mechanism of the photoassisted $\mathrm{CO}_{2}$ methanation promoted by $\mathrm{NiO} / \mathrm{Ni}-\mathrm{G}$ as photocatalyst and, particularly, the possible role of photogenerated electrons and holes, a series of experiments adding probe molecules were performed. Especifically, a series of photocatalytic tests were carried out adding compounds with increasing ability to act as electron donors. It was assumed that if the mechanism of the photoassisted reaction involves charge separation, the presence of additives that could act as sacrificial electron donor or acceptor agents should enhance or stop, respectively, the photocatalytic activity. Ideally the presence of these electron donor/acceptor additives should not influence the thermal methanation mechanism, at least, in a large extent.

Optical band gap (Eg) may be evaluated based on the optical absorption spectrum using the following Equation [66] (Eq. $10)$ :

$$
(A h v)^{n}=B(h v-E g)
$$

Where;

ho : the photon energy,

A : absorbent,

B : a material constant and $\mathrm{n}$ is 2 or $1 / 2$ for direct and indirect transitions, respectively.
The optical band gap for the absorption peak is obtained by extrapolating the linear portion of the (Ahv) ${ }^{n}$ curve versus hv to zero. No linear relation was found for $n=1 / 2$, suggesting that the prepared $\mathrm{NiO} \mathrm{NPs}$ are semiconductors with a direct transition at this energy. The band gap of as-prepared $\mathrm{NiO} /$ graphene nanocomposite was calculated about $3.3 \mathrm{eV}$ (Fig. 5d) which is similar to the values reported by other researchers $[67,68]$. It has a red-shift to that of bulk $\mathrm{NiO}(3.5 \mathrm{eV})$ which could be ascribed to the interaction of $\mathrm{NiO}$ with graphene backbone and large surface of $\mathrm{NiO} /$ graphene nanocomposite $[69,70]$.

Photocatalytic activity and its mechanism

The two mechanisms for photocatalytic activities of pure $\mathrm{NiO}$ and $\mathrm{NiO}$ /graphene nanocomposite were proposed as follows:

The proposed photocatalytic mechanism for pure NiO NPs (Equations 11 to 17):

$$
\begin{aligned}
& \mathrm{UV}+\mathrm{NiO} \rightarrow \mathrm{NiO}\left(h^{+}+\overline{\mathrm{e}}\right) \\
& h^{+}+\mathrm{H}_{2} \mathrm{O} \rightarrow \mathrm{H}^{+}+{ }^{\circ} \mathrm{OH} \\
& 2 h^{+}+2 \mathrm{H}_{2} \mathrm{O} \rightarrow 2 \mathrm{H}^{+}+\mathrm{H}_{2} \mathrm{O}_{2} \\
& \mathrm{H}_{2} \mathrm{O}_{2} \rightarrow{ }^{\circ} \mathrm{OH}+{ }^{\circ} \mathrm{OH} \\
& \overline{\mathrm{e}}+\mathrm{O}_{2} \rightarrow{ }^{\circ} \overline{\mathrm{o}}_{2} \\
& { }^{\circ} \overline{\mathrm{O}}_{2}+20 \mathrm{H}^{\circ}+\mathrm{H}^{+} \rightarrow \mathrm{H}_{2} \mathrm{O}_{2}+\mathrm{O}_{2} \\
& \mathrm{H}_{2} \mathrm{O}_{2} \rightarrow{ }^{\circ} \mathrm{OH}+{ }^{\circ} \mathrm{OH}
\end{aligned}
$$

The proposed photocatalytic mechanism for $\mathrm{NiO}$ /graphene nanocomposite (Equations 18 to 21):

$$
\begin{aligned}
& \mathrm{NiO}+h v \rightarrow\left(\overline{\mathrm{e}}_{\mathrm{CB}}\right)+\left(h^{+}{ }_{\mathrm{VB}}\right) \rightarrow \text { graphene }\left(\overline{\mathrm{e}}+h^{+}\right) \\
& \mathrm{NiO}\left(\overline{\mathrm{e}}_{\mathrm{CB}}\right)+\mathrm{O}_{2, a d s} \rightarrow{ }^{\circ} \overline{\mathrm{O}}_{2} \mathrm{NiO} \rightarrow \mathrm{H}^{2} \mathrm{o} \mathrm{H}+\mathrm{NiO} \\
& \mathrm{NiO}\left(h^{+}{ }_{\mathrm{VB}}\right)+\mathrm{OH}_{\text {ads s }} \rightarrow{ }^{\circ} \mathrm{H}+\mathrm{NiO}
\end{aligned}
$$
graphene $(\overline{\mathrm{e}})+\mathrm{O}_{2, a d s} \rightarrow{ }^{\circ} \overline{\mathrm{O}}_{2}+$ graphene $\rightarrow{ }^{H 20}{ }^{\circ} \mathrm{H}+$ graphene

Although no changes in the XP spectrum of Ni(23)-G before and after the reaction could be observed, we were interested in ascertain the presence of $\mathrm{NiO}$ under the reaction conditions, particularly considering the reductive conditions and the temperature of the methanation. The experimental XPS analysis of $\mathrm{Ni}(23)-\mathrm{G}$ prior reaction was compared to that measured in situ under the reaction conditions. Thus, a Ni(23)-G sample was submitted to $\mathrm{H} 2$ atmosphere at $200 \mathrm{oC}$ for $4 \mathrm{~h}$, measuring in situ the Ni $2 p$ peak in the XPS spectrum without exposure to the ambient. As can be observed, the component related to $\mathrm{Ni} 0$ (nearly $853 \mathrm{eV}$ ) becomes higher under the reaction conditions compared to the sample prior to the reaction. However, the XPS component corresponding to $\mathrm{NiO}$ is still bigger than that of the Ni metal. In fact, the relative percentage of $\mathrm{Ni} 0$ in the sample before and under in situ conditions changed from 15\% to $23.5 \%$, respectively. These measurements clearly confirm that in spite of the reductive conditions, the thin layer of $\mathrm{NiO}$ should be still present, particularly at initial reaction times that is when the $\mathrm{NiO} / \mathrm{Ni}-\mathrm{G}$ photocatalyst exhibits the highest photocatalytic activity. It can be, therefore, suggested that it is in this outermost part of $\mathrm{NiO}$ in contact with $\mathrm{Ni}$ where the reaction takes place.

To gain further information on the reaction mechanism and the role of $\mathrm{Ni}$ in the process, $\mathrm{Ni}(23)-\mathrm{G}$ was placed in a sealed 
reactor and exposed to a $\mathrm{H}_{2}$ atmosphere at $200^{\circ} \mathrm{C}$ for $4 \mathrm{~h}$ and then, the sample was allowed to cool down under Ar flow ensuring the complete removal of $\mathrm{H}_{2}$ gas. Subsequently, the reactor was load only with $\mathrm{CO}_{2}$ and submitted to the general reaction conditions at $200 \mathrm{oC}$ and $2240 \mathrm{~W} / \mathrm{m}^{2}$ illumination. After $18 \mathrm{~h}$ reaction, a detectable amount of $\mathrm{CH} 4$ was measured, suggesting the formation of $\mathrm{Ni}-\mathrm{H}$ species in the first step, without the need of photoactivation that subsequently are able to promote photoassisted $\mathrm{CO}_{2}$ reduction as reported before [71].

According to these mechanisms, it can be said that graphene layers can postpone the recombination process, so the performance of nanocomposite is better than pure NiO NPs. Furthermore, high surface area, the high separation rate of charge carriers, excellent structure, and great electrical and optical properties of graphene layers of nanocomposite can increase the photocatalytic yield of the graphene-based nanocomposite.

Therefore, the photoassisted $\mathrm{CO}_{2}$ reduction using $\mathrm{Ni}(23)-\mathrm{G}$ as promoter was carried out in the presence of dimethylaniline, anisole and p-xylene as electron donors (oxidation potentials of $0.91,1.93$ and $2.18 \mathrm{~V}$ vs. $\mathrm{Ag} / \mathrm{AgCl}$, respectively) and 4-nitrobenzene as electron acceptor quenchers. Note that according to their boiling points the sacrificial agents are in all cases in the gas phase at the reaction temperature. It was observed that the presence of N,N-dimethylaniline $(0.16$ mmol) increases the specific $\mathrm{CO}_{2}$ reduction initial rate by a factor over 2.5 , reaching a value of $1600 \mu \mathrm{mol} / \mathrm{gNi}$.h. $\mathrm{CH}_{4}$ was also formed in the presence of anisole as electron donor, although at much slower initial reaction rate than in the case of $N, N$-dimethylaniline in accordance with its higher oxidation potential. In contrast, the presence of p-xylene (oxidation potential of $2.18 \mathrm{~V}$ vs. $\mathrm{Ag} / \mathrm{AgCl}$ ) completely stopped the production of $\mathrm{CH}_{4}$, since this aromatic molecule would not be able to quench the holes on $\mathrm{Ni}(23)-\mathrm{G}$ due to its high oxidation potential (Fig. 10). In the presence of nitrobenzene acting as electron acceptor quencher, $\mathrm{CO}_{2}$ reduction was also quenched, due to the preferential trapping of electrons by nitrobenzene that has a lower reduction potential compared to $\mathrm{CO}_{2}$. Note that it would be hard to explain any influence of the presence of electron donor/acceptor quenchers at this small concentration if a photothermal mechanism were operating.

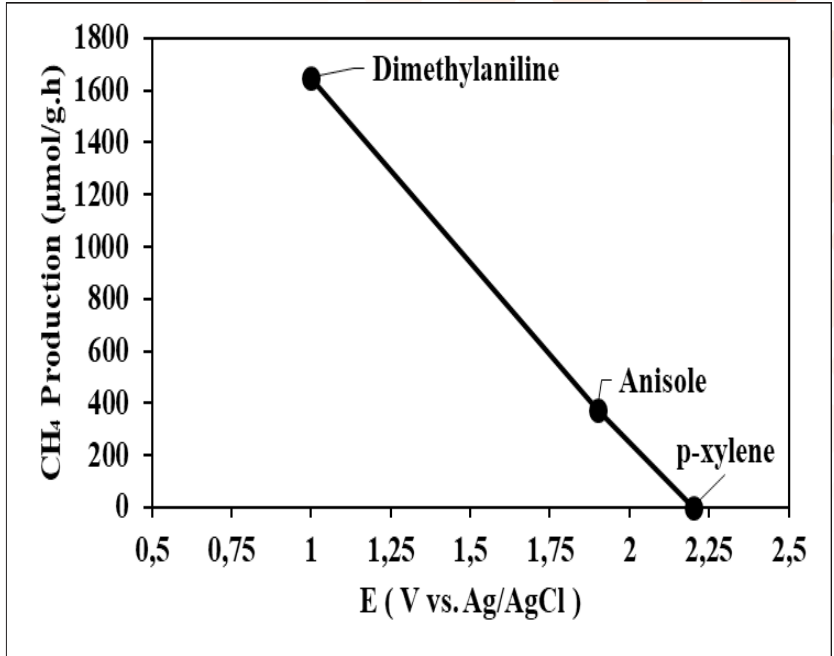

Figure 10: $\mathrm{CH}_{4}$ production as function of the sacrificial agent oxidation potential. The $\mathrm{CH}_{4}$ production rate experimental conditions: at $1 \mathrm{~h}$, at $2240 \mathrm{~W} / \mathrm{m}^{2}$, at $300 \mathrm{~W}$ Xenon lamp, at $200^{\circ} \mathrm{C}$, at $\mathrm{PH}_{2}=1.05$ bar, at $\mathrm{PCO}_{2}$ bar and at $20 \mu \mathrm{l}$ sacrificial agent, respectively.

Transient absorption measurements were carried out to provide support to the generation of charge separation due to the interaction of $\mathrm{NiO} / \mathrm{Ni} \mathrm{NPs}$ and fl-G. Aimed at this purpose, an Ar-purged $f$-G dispersion in acetonitrile $(1 \mathrm{mg} /$ $\mathrm{ml}$ ) was submitted to $355 \mathrm{~nm}$ laser pulse excitation and the transient spectrum was acquired at $30 \mathrm{~ns}$ (Fig. 11a). As can be obtained in Fig. 11 the transient spectrum of the fl-G dispersion corresponds to a continuous band decreasing in intensity towards the red part of the spectrum [72]. This behavior has been observed previously in similar graphenic materials and attributed to the charge separation state decaying in microsecond time scale [72]. In a second control, commercial $\mathrm{NiO}$ NPs $(<50 \mathrm{~nm})$ from Aldrich were partially reduced in an aqueous $\mathrm{N}_{2} \mathrm{H}_{2}$ solution $(50 \% \mathrm{vol})$ to $\mathrm{NiO} / \mathrm{Ni}$ as determined by XRD in order to simulate the $\mathrm{NiO} / \mathrm{Ni}$ NPs that are present on the $\mathrm{NiO} / \mathrm{Ni}-\mathrm{G}$ samples, Then, the partially reduced $\mathrm{NiO} / \mathrm{Ni}$ NPs were dispersed in acetonitrile $(1 \mathrm{mg} / \mathrm{ml})$ and the transient spectrum was also acquired upon $355 \mathrm{~nm}$ laser excitation (Fig. 11a). A negative signal corresponding to the bleaching of $\mathrm{NiO} /$ $\mathrm{Ni}$ ground state absorption was observed. Finally, a small aliquot of the dispersed $\mathrm{NiO} / \mathrm{Ni} \mathrm{NPs}$ corresponding to $0.5 \mathrm{mg}$ was added to the fl-G suspension $(2 \mathrm{mg})$ in acetonitrile and the transient spectrum recorded at $30 \mathrm{~ns}$ upon $355 \mathrm{~nm}$ laser excitation (Fig. 11a). It was observed that addition of $\mathrm{NiO} /$ Ni NPs induces quenching of the signal observed for the $f-\mathrm{G}$ dispersion, supporting the interaction of the charge separation state of $f$-G flakes and the NiO/Ni NPs.

The transient signals of the fl-G, NiO/Ni NPs and fl-G containing Ni NPs were monitored at different wavelengths, obtaining for all the wavelength identical results. Fig. 11b shows the kinetics of the transient signal decay of the three samples monitored at $415 \mathrm{~nm}$. As can be observed, the sample containing fl-G presents a transient decay that can be fitted to a single exponential with a lifetime of $36 \mathrm{~ns}$ (Fig. 11b). 


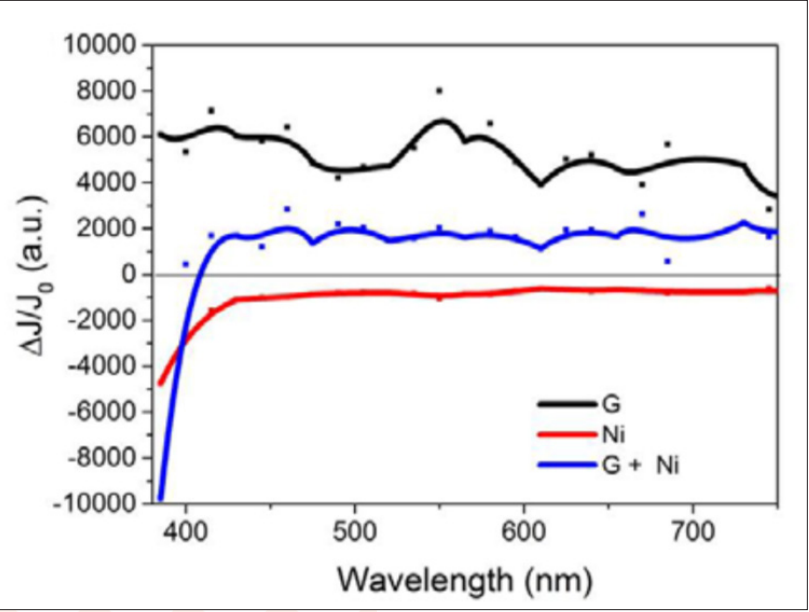

(a)

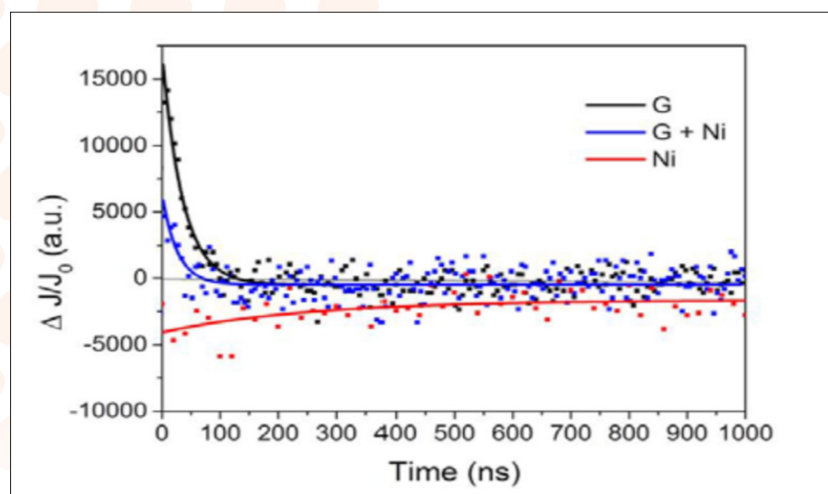

(b)

Figure 11: (a) Transient spectra and (b) kinetics of Ar-purged fl-G (black), NiO/Ni NPs (red) and fl-G with Ni NPs (blue) suspensions. Experimental conditions: at Laser excitation 355 $\mathrm{nm}$, at fl-G acquisition time: $30 \mathrm{~ns}$, at fl-G acquisition time: 500 ns and at Transient kinetics: at $415 \mathrm{~nm}$, respectively.

Therefore, to understand the role of the temperature on the photocatalytic process, a series of experiments adding to the reaction vessel small aliquots of $\mathrm{H}_{2} \mathrm{O}$, in the range of the amounts that should be formed in the methanation, were carried out (Fig. 12). It was reasoned that the value of the activation energy determined from the Arrhenius plot of the logarithm of the relative initial reaction rates with the inverse of the absolute temperature is relatively low for a transition state involving bond cleavage, while this value of activation energy is more common for the heat of $\mathrm{H}_{2} \mathrm{O}$ desorption from the photocatalyst surface. It should be noted that $\mathrm{H}_{2}^{18} \mathrm{O}$ formation was detected in the ${ }^{13} \mathrm{C}^{18} \mathrm{O}_{2}$ labelled experiments. According to the stoichiometry (Eq. 21), methanation of $\mathrm{CO}_{2}$ should also produce two $\mathrm{H}_{2} \mathrm{O}$ molecules and that at low temperatures these molecules could be preferentially adsorbed on the surface of the photocatalyst, resulting in the inhibition of the reaction.

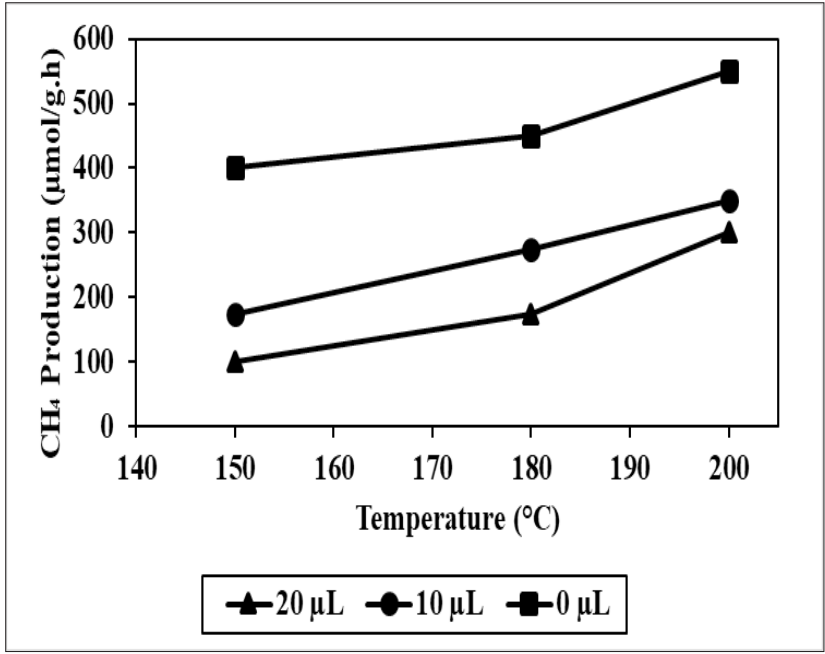

Figure 12: Specific $\mathrm{CH}_{4}$ production rate measured at different reaction temperatures (a) without or upon (b) the addition of 10 $\mu \mathrm{l}$ of $\mathrm{H}_{2} \mathrm{O}$ and (c) the addition of $20 \mu \mathrm{l}$ of $\mathrm{H}_{2} \mathrm{O}$. Experimental conditions: at $2240 \mathrm{~W} / \mathrm{m}^{2}$, at $25 \mathrm{mg} \mathrm{Ni}(23)-\mathrm{G}$ catalyst, at $\mathrm{PH}_{2}$ $=1.05$ and at bar, $\mathrm{PCO}_{2}$ bar, respectively.

In addition of $10 \mu \mathrm{H}_{2} \mathrm{O}$ or $20 \mu \mathrm{H}_{2} \mathrm{O}$ in the reaction media resulted in a detrimental effect on the specific $\mathrm{CH}_{4}$ production rate, proportional to the amount of $\mathrm{H}_{2} \mathrm{O}$, the higher the amount of $\mathrm{H}_{2} \mathrm{O}$ present at any of the temperatures studied, the lower the specific $\mathrm{CH}_{4}$ production rate (Fig. 12). However, it is proposed that a possible role of the temperature in the system could be to favor $\mathrm{H}_{2} \mathrm{O}$ desorption from the photocatalysts surface, giving an opportunity for $\mathrm{H}_{2}$ and $\mathrm{CO}_{2}$ activation. The amount of $\mathrm{H}_{2} \mathrm{O}$ formed at final reaction times should correspond to the addition of $890 \mu \mathrm{l}$ and that the amount of $\mathrm{H}_{2} \mathrm{O}$ tested in Fig. 12 is similar to the amount formed at the early stages of methanation. Even with these relatively low $\mathrm{H}_{2} \mathrm{O}$ concentrations, their negative influence is already clearly observed in Fig. 12.

Therefore, it is clear that $\mathrm{H}_{2} \mathrm{O}$ is a strong poison of the photomethanation and, it is proposed that the role of the temperature is to desorb this generated $\mathrm{H}_{2} \mathrm{O}$ acting as poison from the catalyst surface. Finally, the photocatalytic activity of the $\mathrm{NiO} / \mathrm{Ni}-\mathrm{G}$ catalyst was evaluated under continuous flow operation. Continuous flow is very convenient to test photocatalyst stability and the influence of the contact time on the conversion. In the present study, $14.79 \mathrm{ml} / \mathrm{min}$ total flow containing, $76.8 \% \mathrm{~N}_{2}, 18.8 \% \mathrm{H}_{2}$ and $4.4 \% \mathrm{CO}_{2}$ was passed through a cylindrical quartz reactor containing 50.7 $\mathrm{mg} \mathrm{Ni}(23)-\mathrm{G}$ photocatalyst loaded on the top of a fritted glass filter inside the reactor. Considering the $0.75 \mathrm{ml}$ photocatalyst volume and the gas flow, the contact time of $\mathrm{CO}_{2}$ with the irradiated catalysts was $3.1 \mathrm{~s}$. The cylindrical photoreactor was heated at $200^{\circ} \mathrm{C}$ by means of an electrical heating ribbon controlled with a thermocouple and the irradiation was carried out using the same light source used in the previous experiments, but the light intensity at the photocatalyst was $754.7 \mathrm{~W} / \mathrm{m}^{2}$.

Basic principle of photocatalytic $\mathrm{CO}_{2}$ reduction

The basic principle of $\mathrm{CO}_{2}$ reduction with $\mathrm{H}_{2} \mathrm{O}$ photocatalysis 
occurs when the energy of the photons is enough to promote the electrons (Fig. 8) in the VB to jump to the CB. This occurs in three steps:

- photon absorption and electron-hole pair generation,

- charge separation and migration to surface reaction sites or to recombination sites, and

- surface chemical reactions at the active sites containing donor oxidants at the VB holes and acceptor reductants at the electron center (Fig. 4). Numerous defects associated with these photocatalytic principles have been identified by researchers. During photocatalysis, cation radicals can be produced by injecting charges from an excited molecule into the CB of graphene (Fig. 8) [73].

Irradiation is usually the initial process of $\mathrm{CO}_{2}$ reduction with $\mathrm{H}_{2} \mathrm{O}$ photocatalysis; thus, the excitation of electrons by photons at the ground state is the prerequisite. Periodically, the photoexcitation of electrons at the ground state also occurs in most of the materials adsorbed on the surface of graphene for example, the reaction occurring in dye-sensitized solar cells [74-77]. Different pathways are mainly experienced by the charge carriers. Most individual graphene materials are primarily used for water splitting and oxidation/reduction (Fig. $12)$ in both suspension and electrode systems [78,79].

As commented above, the photoassisted $\mathrm{CO}_{2}$ reduction by $\mathrm{NiO} / \mathrm{Ni}-\mathrm{G}$ requires the combination of heating and irradiation to occur. The influence of light intensity and temperature on the photocatalytic $\mathrm{CO}_{2}$ reduction reaction using $\mathrm{Ni}(23)-\mathrm{G}$ was, therefore, studied to establish this dependency. The results are presented in Fig. 8.

\section{$\mathrm{CO}_{2}$ reduction with $\mathrm{H}_{2} \mathrm{O}$}

Recently, the increased population as well as industrialization has been detrimental to the environment including the atmosphere $[80,81]$. Recent increase in $\mathrm{CO}_{2}$ has remained to be a major issue on this planet $[82,83]$. $\mathrm{CO}_{2}$ produced with $\mathrm{H}_{2} \mathrm{O}$ from burning fuels from the domestic to industrial level has contributed significantly to the atmospheric air pollution, resulting in the current global warming the world is experiencing [84-87]. There has been an introduction of alternative advanced strategies to cut down the production of $\mathrm{CO}_{2}$. The SDG 7 has been identified for clean and renewable energy as one of the best mechanisms to reduce the production of $\mathrm{CO}_{2}$ with $\mathrm{H} 2 \mathrm{O}$ in the atmosphere $[88,89]$. Therefore, due to the increasing demand of fuel and production on the industrial scale, the contribution of $\mathrm{CO}_{2}$ is still high. Technologies have been developed to reduce the amount of produced $\mathrm{CO}_{2}$. Among others, the photocatalytic reaction is one of the best technologies for $\mathrm{CO}_{2}$ reduction (Fig. 13) [50].

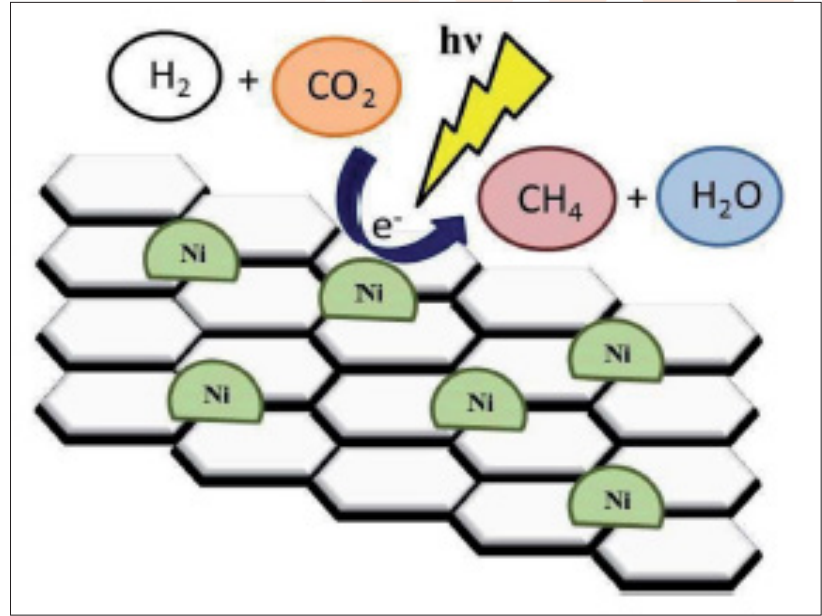

Figure 13: The photoreduction of $\mathrm{CO}_{2}$ with $\mathrm{H}_{2} \mathrm{O}$ to $\mathrm{CO}$.

In order to confirm the origin of the $\mathrm{C}$ source in the $\mathrm{CH}_{4}$ production and the formation of $\mathrm{H}_{2} \mathrm{O}$ according to Eq. 22 ${ }^{13} \mathrm{C}^{18} \mathrm{O}_{2}$ was used as substrate and the obtained products were analyzed after $2 \mathrm{~h}$ reaction under optimal conditions by GCMS spectroscopy (Fig. 10).

$\mathrm{CO}_{2}+4 \mathrm{H}_{2} \rightarrow \mathrm{CH}_{4}+2 \mathrm{H}_{2} \mathrm{O} \Delta \mathrm{G}=-115 \mathrm{KJ} / \mathrm{mol}$

The analysis shows a mix of $14 \%$ of unlabeled ${ }^{12} \mathrm{CH}_{4}$ and $86 \%$ of ${ }^{13} \mathrm{CH}_{4}$, indicating that a minor portion of the produced $\mathrm{CH}_{4}$ does not come from the labelled substrate. The most likely origin of the unlabeled $\mathrm{CH}_{4}$ should be the $\mathrm{C}$ atoms of $f$-G. In order to confirm this hypothesis a stability experiment was performed submitting $\mathrm{Ni}(23)-\mathrm{G}$ sample at reaction conditions $\left(200^{\circ} \mathrm{C}\right.$ and $\left.2240 \mathrm{~W} / \mathrm{m}^{2}\right)$ under Ar atmosphere, and measuring the $\mathrm{CO}_{2}$ evolution (Fig. 11). As can be observed a small amount of $\mathrm{CO}_{2}$ was observed to evolve under these conditions for the first $20 \mathrm{~h}$. After this period, the $\mathrm{CO}_{2}$ amount remained constant, confirming, on the one hand, the presence of small amounts of $\mathrm{CO}_{2}$ originated from $f$ - $\mathrm{G}$ and, on the other hand, that the photocatalyst is photostable at long reaction times. It should be, however, reminded that the blank experiment with $f-\mathrm{G}$ in where formation of $\mathrm{CH}_{4}$ was not observed, indicates that even for this contribution of unlabeled $\mathrm{CH}_{4}$, the presence of $\mathrm{NiO} / \mathrm{Ni}$ is needed. In the same experiment using ${ }^{13} \mathrm{C}^{18} \mathrm{O}_{2}$, observation of $\mathrm{H}_{2}{ }^{18} \mathrm{O}$ was also detected (Fig. 10), confirming the formation of $\mathrm{H}_{2} \mathrm{O}$ in the methanation. $\mathrm{CH}_{4}$ production efficiencies was showed for different $\mathrm{N} / \mathrm{NiO}$-graphene nanocomposites ratios during photocatalysis process in Table 2. 99\% maximum $\mathrm{CH}_{4}$ production efficieny was measured at $\mathrm{Ni} / \mathrm{NiO}(23)-\mathrm{G}$ nanocomposite after $\mathrm{CO}_{2}$ reduction during photocatalysis process, at $200^{\circ} \mathrm{C}$, at $2240 \mathrm{~W} / \mathrm{m}^{2}$, at $300 \mathrm{~W}$ Xe lamp irradiation, at $\mathrm{P}_{\mathrm{H} 2}=1.05$ bar and $\mathrm{PCO} 2=0.25$ bar, respectively (Table 2 ). 


\begin{tabular}{|l|l|l|l|l|l|}
\hline Samples & $\mathrm{CH}_{4}$ production (\%) & Samples & $\mathrm{CH}_{4}$ production (\%) & Samples & $\mathrm{CH}_{4}$ production (\%) \\
\hline $\mathrm{Ni}(6)-\mathrm{G}$ & 5 & $\mathrm{NiO}(6)-\mathrm{G}$ & 13 & $\mathrm{Ni} / \mathrm{NiO}(6)-\mathrm{G}$ & 24 \\
\hline $\mathrm{Ni}(10)-\mathrm{G}$ & 7.5 & $\mathrm{NiO}(10)-\mathrm{G}$ & 21 & $\mathrm{Ni} / \mathrm{NiO}(10)-\mathrm{G}$ & 40 \\
\hline $\mathrm{Ni}(14)-\mathrm{G}$ & 10 & $\mathrm{NiO}(14)-\mathrm{G}$ & 30 & $\mathrm{Ni} / \mathrm{NiO}(14)-\mathrm{G}$ & 61 \\
\hline $\mathrm{Ni}(20)-\mathrm{G}$ & 18 & $\mathrm{NiO}(20)-\mathrm{G}$ & 42 & $\mathrm{Ni} / \mathrm{NiO}(20)-\mathrm{G}$ & 85 \\
\hline $\mathrm{Ni}(23)-\mathrm{G}$ & 25 & $\mathrm{NiO}(23)-\mathrm{G}$ & 53 & $\mathrm{Ni} / \mathrm{NiO}(23)-\mathrm{G}$ & 99 \\
\hline
\end{tabular}

Table 2: $\mathrm{CH}_{4}$ production efficiencies at different $\mathrm{Ni} / \mathrm{NiO}$-graphene $(\mathrm{G})$ nanocompoasite samples, at $200^{\circ} \mathrm{C}$, at $2240 \mathrm{~W} / \mathrm{m}^{2}$, at 300 W Xe lamp irradiation, at $\mathrm{P}_{\mathrm{H} 2}=1.05$ bar and $\mathrm{PCO}_{2}=0.25$ bar, respectively.

Zhou and co-workers described the facile in situ synthesis of a graphene $\left(\mathrm{g}_{-} \mathrm{C}_{3} \mathrm{~N}_{4}\right)-\mathrm{N}-\mathrm{TiO}_{2}$ heterojunction as a competent photocatalyst for the selective photoreduction of $\mathrm{CO}_{2}$ with $\mathrm{H}_{2} \mathrm{O}$ to $\mathrm{CO}$. The composites of graphene, i.e., carbon nitride and $\mathrm{N} 2$-doped $\mathrm{TiO} 2$ composites $\left(\mathrm{g}-\mathrm{C}_{3} \mathrm{~N}_{4}-\mathrm{N}-\mathrm{TiO}_{2}\right)$ were in situ synthesized by the thermal treatment of well-mixed urea and $\mathrm{Ti}(\mathrm{OH})_{4}$ in an alumina crucible with a cover at different mass ratios. These results prove that graphene has high photocatalytic $\mathrm{CO}_{2}$ reduction with $\mathrm{H}_{2} \mathrm{O}$ as compared to its precursors [90].

Photo-assisted $\mathrm{CO}_{2}$ reduction with $\mathrm{H}_{2} \mathrm{O}$ by $\mathrm{H}_{2}$ has been repeatedly described using fabrics covering noble or analytical metals, such as $\mathrm{Pd}, \mathrm{Ru}$ and In [28-31,91,92]. It was found that $\mathrm{H}_{2} \mathrm{O}$ formed in the photocatalytic reaction of $\mathrm{NiO} / \mathrm{Ni}$ NPs supported on defective graphene via photo-assisted $\mathrm{CO}_{2}$ reduction with $\mathrm{H}_{2}$ has a negative influence on the photocatalytic activity and studies further confirmed that $\mathrm{H}_{2} \mathrm{O}$ desorption is one of the reasons why the system requires heating [93]. Therefore, it is anticipated that a promising function of temperature in the system can be to promote $\mathrm{H}_{2} \mathrm{O}$ desorption from the photocatalyst surface, providing an opportunity for $\mathrm{H}_{2}$ and $\mathrm{CO}_{2}$ activation $[36,38]$.

\section{Conclusion}

The preparation of $\mathrm{NiO} /$ graphene nanocomposite can help to delay the recombination process, so the photocatalytic performance improves. Hence, $\mathrm{NiO}$ /graphene nanocomposite was identified as an effective adsorbent and photocatalyst in waste-water treatment because of it shows an excellent performance to remove pollutants, rapidly.

Finally, in the present study, it has been shown that $\mathrm{NiO} / \mathrm{Ni}$ NPs supported on $f l-\mathrm{G}$ is a suitable photocatalyst to perform methanation of $\mathrm{CO}_{2}$ at temperatures about $200^{\circ} \mathrm{C}$, reaching specific $\mathrm{CH}_{4}$ formation rates of $642 \mu \mathrm{mol} / \mathrm{gNi}$.h that are about double than that measured for Ni NPs supported on high surface area silica-alumina and apparent quantum yields of $1.98 \%$. 99\% maximum $\mathrm{CH}_{4}$ production efficieny was measured at $\mathrm{Ni} / \mathrm{NiO}(23)-\mathrm{G}$ nanocomposite after $\mathrm{CO}_{2}$ reduction during photocatalysis process, at $200^{\circ} \mathrm{C}$, at $2240 \mathrm{~W} / \mathrm{m}^{2}$, at 300 W Xe lamp irradiation, at $\mathrm{P}_{\mathrm{H} 2}=1.05$ bar and $\mathrm{PCO}_{2}=0.25$ bar, respectively.

In addition to, the positive effect of graphene appears to be due to the photoinduced electron transfer from excited $\mathrm{NiO} /$ $\mathrm{Ni}$ NPs to the graphene sheet. Experimental evidence indicates that the role of the temperature is to desorb $\mathrm{H}_{2} \mathrm{O}$ formed also in the process, causing apparent deactivation of the photocatalyst.
Under optimal conditions and under continuous flow, photocatalyst deactivation was reduced probably to the more favorable $\mathrm{H}_{2} \mathrm{O}$ removal. Mechanistic data using electron donor, acceptor quenchers and observation of $f$-G charge separated stated quenching by $\mathrm{NiO} / \mathrm{Ni} \mathrm{NPs}$ support that the reaction mechanism involves photogenerated charge separation derived from photon absorption in the UV region.

\section{Acknowledgements}

This research study was undertaken in the Environmental Microbiology Laboratury at Dokuz Eylul University Engineering Faculty Environmental Engineering Department, Izmir, Turkey.

\section{References}

1. Hu B, Guild C, Suib SL (2013) Thermal, electrochemical, and photochemical conversion of $\mathrm{CO}_{2}$ to fuels and valueadded products. $\mathrm{J} \mathrm{CO}_{2}$ Util 1: 18-27.

2. Maeda C, Miyazaki Y, Ema T (2014) Recent progress in catalytic conversions of carbon dioxide. Catal Sci Technol 4: 1482-1497.

3. Park SM, Razzaq A, Park YH, Sorcar S, Park Y, et al. (2016) Hybrid CuxO- $\mathrm{TiO}_{2}$ Heterostructured composites for photocatalytic $\mathrm{CO}_{2}$ reduction into methane using solar 1rradiation: sunlight into fuel. American Chemical Society (ACS) Publications Omega 1: 868-875.

4. Habisreutinger SN, Schmidt-Mende L, Stolarczyk JK (2013) Photocatalytic Reduction of $\mathrm{CO}_{2}$ on $\mathrm{TiO}_{2}$ and Other Semiconductors. Angew Chem Int Ed 52: 7372-7408.

5. Huang C, Li Z, Zou ZA (2016) Perspective on Perovskite Oxide Semiconductor Catalysts for Gas Phase Photoreduction of Carbon Dioxide. MRS Commun 6: 216-225.

6. Ran J, Jaroniec M, Qiao SZ (2018) Cocatalysts in Semiconductor-based Photocatalytic $\mathrm{CO}_{2}$ Reduction: Achievements, Challenges, and Opportunities. Adv Mate 30: 1704649-1704680.

7. El-Khouly ME, El-Mohsnawy E, Fukuzumi S (2017) Solar Energy Conversion: from Natural to Artificial Photosynthesis. J Photochem Photobiol C Photochem Rev 31: 36-83.

8. Takeda H, Ishitani O (2010) Development of Efficient Photocatalytic Systems for $\mathrm{CO}_{2}$ Reduction Using Mononuclear and Multinuclear Metal Complexes Based on Mechanistic Studies. Coord Chem Rev 254: 346-354.

9. Liu X, Inagaki S, Gong J (2016) Heterogeneous Molecular Systems for Photocatalytic $\mathrm{CO}_{2}$ Reduction with Water Oxidation. Angew Chem Int Ed 55: 14924-14950. 
10. Hong J, Zhang W, Ren J, Xu R (2013) Photocatalytic Reduction of $\mathrm{CO}_{2}$ : A Brief Review on Product Analysis and Systematic Methods. Anal Methods 5: 1086-1097.

11. Fan W, Zhang Q, Wang Y (2013) Semiconductor-based Nanocomposites for Photocatalytic $\mathrm{H}_{2}$ Production and $\mathrm{CO}_{2}$ Conversion. Phys Chem Chem Phys 15: 2632-2649.

12. Mao J, Li K, Peng T (2013) Recent Advances in the Photocatalytic $\mathrm{CO}_{2}$ Reduction over Semiconductors. Catal Sci Technol 3: 2481-2498.

13. Yin S, Han J, Zhou T, Xu R (2015) Recent Progress in g-C3N4 Based Low Cost Photocatalytic System: Activity Enhancement and Emerging Applications. Catal Sci Technol 5: 5048-5061.

14. Chang X, Wang T, Gong J (2016) $\mathrm{CO}_{2}$ Photo-reduction: Insights into $\mathrm{CO}_{2}$ Activation and Reaction on Surfaces of Photocatalysts. Energy Environ Sci 9: 2177-2196.

15. Dasab S, Wan Daud WMA (2014) A Review on Advances in Photocatalysts Towards $\mathrm{CO}_{2}$ Conversion. RSC Adv 4: 20856-20893.

16. Kou J, Lu C, Wang J, Chen Y, Xu Z, et al. (2017). Selectivity Enhancement in Heterogeneous Photocatalytic Transformations. Chem Rev 117: 1445-1514.

17. Low J, Yu J, Ho W (2015) Graphene-Based Photocatalysts for $\mathrm{CO}_{2}$ Reduction to Solar Fuel, The Journal of Physical Chemistry Letters 6: 4244-4251.

18. Akhundi A, Habibi-Yangjeh A, Abitorabi M, Pouran SR (2019) Review on photocatalytic conversion of carbon dioxide to value-added compounds and renewable fuels by graphitic carbon nitride-based photocatalysts, Catalysis Reviews 61: 595-628.

19. Park S, Ruoff RS (2009) Chemical methods for the production of graphenes. Nat Nanotechnol 4: 217-224.

20. Geim AK (2009) Graphene: Status and prospects. Science 324: 1530-1534.

21. Shen J, Shi M, Yan B, Ma H, Li N, Ye M (2011) Ionic liquid-assisted one-step hydrothermal synthesis of $\mathrm{TiO}_{2}$ reduced graphene oxide composites. Nano Res 4: 795806.

22. Chen C, Cai W, Long M, Zhou B, Wu Y, et al. (2010) Synthesis of visible-light responsive graphene oxide/ TiO2composites with $\mathrm{p} / \mathrm{n}$ heterojunction. ACS Nano 4: 6425-6432.

23. Li Q, Guo B, Yu J, Ran J, Zhang B, et al. (2011) Highly efficient visible-light-driven photocatalytic hydrogen production of CdS-cluster-decorated graphene nanosheets. J Am Chem Soc 133: 10878-10884.

24. Perera SD, Mariano RG, Vu K, Nour N, Seitz O, et al. (2012) Hydrothermal synthesis of graphene-TiO2 nanotube composites with enhanced photocatalytic activity. ACS Catal 2: 949-956.

25. Shin HJ, Kim KK, Benayad A, Yoon SM, Park HK, et al. (2009) Efficient reduction of graphite oxide by sodium borohydride and its effect on electrical conductance. Adv Funct Mater 19: 1987-1992.

26. Liang YT, Vijayan BK, Gray KA, Hersam MC (2011) Minimizing graphene defects enhances titania nanocomposite-based photocatalytic reduction of $\mathrm{CO}_{2}$ for improved solar fuel production. Nano Lett 11: 2865-2870.
27. Ong WJ, Tan LL, Chai SP, Yong ST, Mohamed AR (1998) Self-Assembly of Nitrogen-Doped $\mathrm{TiO}_{2}$ with Exposed $\{001\}$ Facets on the Graphene Scaffold as Photo-Active Hybrid Nanostructures for Reduction of Carbon Dioxide to Methane, Nano Research 20-44.

28. O'Brien PG, Sandhel A, Wood TE, Jelle AA, Hoch LB, et al. (2014). Photomethanation of Gaseous $\mathrm{CO}_{2}$ over $\mathrm{Ru} /$ Silicon Nanowire Catalysts with Visible and Near-Infrared Photons, Advanced Science 1: 1400001.

29. Li M, Li P, Chang K, Wang T, Liu L, et al. (2015) Highly efficient and stable photocatalytic reduction of $\mathrm{CO}_{2}$ to $\mathrm{CH}_{4}$ over $\mathrm{Ru}$ loaded $\mathrm{NaTaO}_{3}$, Chemical Communications 51: 7645-7648.

30. Ghuman KK, Hoch LB, Szymanski P, Loh JYY, Kherani NP, et al. (2016) Photoexcited Surface Frustrated Lewis Pairs for Heterogeneous Photocatalytic $\mathrm{CO}_{2}$ Reduction, Journal of the American Chemical Society 138: 12061214.

31. Ren J, Ouyang S, Xu H, Meng X, Wang T, et al. (2017) Targeting Activation of $\mathrm{CO}_{2}$ and $\mathrm{H}-2$ over Ru-Loaded Ultrathin Layered Double Hydroxides to Achieve Efficient Photothermal $\mathrm{CO}_{2}$ Methanation in Flow-Type System, Adv Energy Mater 7: 1601657.

32. Inui T, Funabiki M, Suehiro M, Sezume T (1979) Methanation of $\mathrm{CO}_{2}$ and $\mathrm{CO}$ on supported nickel-based composite catalysts, Journal of the Chemical SocietyFaraday Transactions I 75: 787-802.

33. Du G, Lim S, Yang Y, Wang C, Pfefferle L, et al. (2007) Methanation of carbon dioxide on Ni-incorporated MCM41 catalysts: The influence of catalyst pretreatment and study of steady-state reaction, Journal of Catalysis 249: 370-379.

34. Pan YX, Liu CJ, Ge Q (2010) Effect of surface hydroxyls on selective $\mathrm{CO}_{2}$ hydrogenation over Ni-4/gamma-Al2O3: A density functional theory study, Journal of Catalysis 27: 227-234.

35. Abello S, Berrueco C, Montane D (2013) High-loaded nickel-alumina catalyst for direct $\mathrm{CO} 2$ hydrogenation into synthetic natural gas (SNG), Fuel 113: 598-609.

36. Frontera P, Macario A, Ferraro M, Antonucci P (2017) Supported Catalysts for $\mathrm{CO}_{2}$ Methanation: A Review Catalysts 7: 59-87.

37. Rao CNR, Sood AK, Subrahmanyam KS, Govindaraj A (2009) Graphene: The New Two-Dimensional Nanomaterial, Angewandte Chemie International Edition 48: 7752-7777.

38. Mateo D, Esteve-Adell I, Albero J, Primo A, García H (2017) Oriented 2.0.0 $\mathrm{Cu}_{2} \mathrm{O}$ nanoplatelets supported on few-layers graphene as efficient visible light photocatalyst for overall water splitting, Applied Catalysis B: Environmental 201: 582-590.

39. Wang K, Li Q, Liu B, Cheng B, Ho W, et al. (2015) Sulfurdoped $g-\mathrm{C}_{3} \mathrm{~N}_{4}$ with enhanced photocatalytic $\mathrm{CO}_{2}$-reduction performance, Applied Catalysis B: Environmental 176: 44-52.

40. Gusain R, Kumar P, Sharma OP, Jain SL, Khatri OP (2016) Reduced graphene oxide- $\mathrm{CuO}$ nanocomposites for photocatalytic conversion of $\mathrm{CO}_{2}$ into methanol 
under visible light irradiation, Applied Catalysis B: Environmental 181: 352-362.

41. Kumar P, Joshi C, Barras A, Sieber B, Addad A, et al. (2017) Core-shell structured reduced graphene oxide wrapped magnetically separable rGO@CuZnO@ $\mathrm{Fe}_{3} \mathrm{O}_{4}$ microspheres as superior photocatalyst for $\mathrm{CO} 2$ reduction under visible light, Applied Catalysis B: Environmental 205: 654-665.

42. Nikokavoura A, Trapalis C (2017) Alternative photocatalysts to $\mathrm{TiO}_{2}$ for the photocatalytic reduction of $\mathrm{CO}_{2}$, Applied Surface Science 391: 149-174.

43. Primo A, Atienzar P, Sanchez E, Delgado JM, Garcia H (2012) From biomass wastes to large-area, highquality, N-doped graphene: catalyst-free carbonization of chitosan coatings on arbitrary substrates, Chemical Communications 48: 9254-9256.

44. Williams G, Seger B, Kamat PV (2008) $\mathrm{TiO}_{2}$-graphene nanocomposites. UV-assisted photocatalytic reduction of graphene oxide, Acs Nano 2: 1487-1491.

45. Zhang H, Lv X, Li Y, Wang Y, Li J (2010) P25-Graphene Composite as a High Performance Photocatalyst, Acs Nano 4: 380-386.

46. Xiang Q, Yu J, Jaroniec M (2012) Graphene-based semiconductor photocatalysts, Chemical Society Reviews 41: 782-796.

47. Faezeh Soofivand F, Masoud Salavati-Niasari M (2017) Step synthesis and photocatalytic activity of $\mathrm{NiO} /$ graphene nanocomposite under UV and visible light as an effective photocatalyst, Journal of Photochemistry and Photobiology A: Chemistry 337: 44-53.

48. Hummers WS, Offeman RE (1958) Preparation of graphitic oxide, Journal of the American Chemical Society 80: 1339-1339.

49. Chen CM, Zhang Q, Huang JQ, Zhang W, Zhao XC, et al. (2012) Chemically derived graphene-metal oxide hybrids as electrodes for electrochemical energy storage: pre-graphenization or post-graphenization?, Journal of Materials Chemistry 22: 13947-13955.

50. He Y, Zhang L, Fan M, Wang X, Walbridge ML, et al. (2015) Z-scheme $\mathrm{SnO}_{2} \mathrm{X} / \mathrm{g}-\mathrm{C}_{3} \mathrm{~N}_{4}$ composite as an efficient photocatalyst for dye degradation and photocatalytic $\mathrm{CO} 2$ reduction, Sol Energy Mater Sol Cells 137: 175-184.

51. Kim HR, Razzaq A, Heo HJ, In SI (2013) Photocatalytic conversion of $\mathrm{CO}_{2}$ into hydrocarbon fuels with standard titania (degussa P25) using newly installed experimental setup. Rapid Commun Photosci 2: 64-66.

52. Oh WC, Zhang FJ, Chen ML (2010) Characterization and photodegradation characteristics of organic dye for Pttitania combined multi-walled carbon nanotube composite catalysts, Journal of industrial and engineering chemistry 16: 321-326.

53. Singh MK, Agarwal A, Gopal R, Swarnkar RK, Kotnala RK (2011) Dumbbell shaped nickel nanocrystals synthesized by a laser induced fragmentation method, Journal of Materials Chemistry 21: 11074-11079.

54. Blandez JF, Esteve-Adell I, Primo A, Alvaro M, García H (2016) Nickel nanoparticles supported on graphene as catalysts for aldehyde hydrosilylation, Journal of
Molecular Catalysis A: Chemical 412: 13-19.

55. Biesinger MC, Payne BP, Lau LWM, Gerson A, Smart RSC (2009) X-ray photoelectron spectroscopic chemical state quantification of mixed nickel metal, oxide and hydroxide systems, Surface and Interface Analysis 41: 324-332.

56. Ngo A, Bonville P, Pileni M (1999) Nanoparticles of: Synthesis and superparamagnetic properties, The European Physical Journal B-Condensed Matter and Complex Systems 9: 583-592.

57. Khadar MA, Biju V, Inoue A (2003) Effect of finite size on the magnetization behavior of nanostructured nickel oxide, Materials research bulletin 38: 1341-1349.

58. Néel L (1952) Théorie du traînage magnétique de diffusion, Journal de Physique et le Radium 13: 249-264.

59. Kisan B, Shyni P, Layek S, Verma H, Hesp D, et al. (2014) Finite size effects in magnetic and optical properties of antiferromagnetic $\mathrm{NiO}$ nanoparticles, Magnetics, IEEE Transactions on 50: 1-4.

60. Tiwari, S. and Rajeev, K. (2005). Signatures of spin-glass freezing in $\mathrm{NiO}$ nanoparticles, Physical Review B, 72, 104433.

61. Li, L., Chen, L., Qihe, R. and Li, G. (2006). Magnetic crossover of $\mathrm{NiO}$ nanocrystals at room temperature, Applied physics letters, 89, 134102.

62. Peck, M., Huh, Y., Skomski, R., Zhang, R., Kharel, P., Allison, M., Sellmyer, D. and Langell, M. (2011). Magnetic properties of $\mathrm{NiO}$ and $(\mathrm{Ni}, \mathrm{Zn}) \mathrm{O}$ nanoclusters, Journal of Applied Physics, 109, 07B518.

63. Mandal, S., Menon, K.S., Mahatha, S. and Banerjee, S. (2011). Finite size versus surface effects on magnetic properties of antiferromagnetic particles, Applied Physics Letters, 99, 232507.

64. Mahfouz R, Cadete Santos Aires FJ, Brenier A, Jacquier B, Bertolini JC (2008) Synthesis and physico-chemical characteristics of nanosized particles produced by laser ablation of a nickel target in water, Applied Surface Science 254: 5181-5190.

65. Elango G, Roopan SM, Dhamodaran KI, Elumalai K, AlDhabi NA, Arasu MV (2016) Spectroscopic investigation of biosynthesized nickel nanoparticles and its larvicidal, pesticidal activities, Journal of Photochemistry and Photobiology B: Biology 162: 162-167.

66. Hagfeldt A, Graetzel M (1995) Light-induced redox reactions in nanocrystalline systems, Chemical Reviews 95: 49-68.

67. Salavati-Niasari M, Davar F, Fereshteh Z (2010a) Synthesis of nickel and nickel oxide nanoparticles via heattreatment of simple octanoate precursor, Journal of alloys and Compounds 494: 410-414.

68. Salavati-Niasari M, Mir N, Davar F (2010b) A novel precursor in preparation and characterization of nickel oxide nanoparticles via thermal decomposition approach, Journal of Alloys and Compounds 493: 163-168.

69. Xu Y, Schoonen MA (2000) The absolute energy positions of conduction and valence bands of selected semiconducting minerals, American Mineralogist 85: 543-556.

70. Liu Q, Liu Z, Zhang X, Yang L, Zhang N, et al. (2009) 
Polymer photovoltaic cells based on solution-processable graphene and P3HT, Advanced Functional Materials 19: 894-904.

71. Sastre F, Puga AV, Liu L, Corma A, García H (2014) Complete Photocatalytic Reduction of $\mathrm{CO}_{2}$ to Methane by $\mathrm{H}_{2}$ under Solar Light Irradiation, Journal of the American Chemical Society 136: 6798-6801.

72. Baldoví HG, Álvaro M, Ferrer B, García H (2016) Photoinduced Charge Separation on the Microsecond Timescale in Graphene Oxide and Reduced Graphene Oxide Suspensions, ChemPhysChem 17: 958-962.

73. Nasr C, Vinodgopal K, Fisher L, Hotchandani S, Chattopadhyay AK, et al. (1996) Environmental photochemistry on semiconductor surfaces. Visible light induced degradation of a textile diazo dye, naphthol blue black, on TiO2 nanoparticles, J Phys Chem 100: 84368442.

74. Nosaka Y, Nosaka AY (2017) Generation and Detection of Reactive Oxygen Species in Photocatalysis, Chem. Rev 117: 11302-11336.

75. Adormaa BB, Darkwah WK, Ao Y (2018) Oxygen vacancies of the $\mathrm{TiO}_{2}$ nano-based composite photocatalysts in visible light responsive photocatalysis, RSC Adv 8: 33551

76. Li T, Zhao L, He Y, Cai J, Luo M, et al. (2013) Synthesis of $\mathrm{g}-\mathrm{C}_{3} \mathrm{~N}_{4} / \mathrm{SmVO}_{4}$ composite photocatalyst with improved visible light photocatalytic activities in RhB degradation, Appl Catal B 129: 255-263.

77. Hollmann D, Karnahl M, Tschierlei S, Kailasam K, Schneider M, et al. (2014) Structure-Activity Relationships in Bulk Polymeric and Sol-Gel-Derived Carbon Nitrides during Photocatalytic Hydrogen Production, Chem. Mater 26: $1727-1733$

78. Nakamura I, Negishi N, Kutsuna S, Ihara T, Sugihara S, et al. (2000) Role of oxygen vacancy in the plasmatreated $\mathrm{TiO}$ photocatalyst with visible light activity for NO removal, J Mol Catal A: Chem 161: 205-212.

79. Gholipour MR, Dinh CT, B'elandb F, Do TO (2015) Nanocomposite heterojunctions as sunlight-driven photocatalysts for hydrogen production from water splitting, Nanoscale, 7: 8187-8208.

80. Manahan SE (2000) The endangered Global Atmosphere, in Environmental Chemistry, Lewis Publisher, Boca Raton, Landon, New York, Washington D.C, 7th edn.

81. Darkwah WK, Oswald KA (2019) Photocatalytic Applications of Heterostructure Graphitic Carbon Nitride: Pollutant Degradation, Hydrogen Gas Production (water splitting), and $\mathrm{CO}_{2}$ Reduction, Nanoscale Res Lett.

82. Chakravarty S, Chikkatur A, de Coninck H, Pacala S, Socolow R, et al. (2009) Sharing global $\mathrm{CO}_{2}$ emission reductions among one billion high emitters, Proc Natl Acad Sci U S A 106: 11884-11888.

83. Rogelj J, Luderer G, Pietzcker RC, Kriegler E, Schaeffer M, et al. (2015) Energy system transformations for limiting end-of-century warming to below $1.5^{\circ} \mathrm{C}$, Nat Clim Change 5: 519-527.

84. Duguma LA, Minang PA, Van Noordwijk M (2014) Climate Change Mitigation and Adaptation in the Land
Use Sector: From Complementarity to Synergy, Environ Manage 54: 420-432.

85. Yu W, Xu D, Peng T (2015) Enhanced photocatalytic activity of $\mathrm{g}-\mathrm{C}_{3} \mathrm{~N}_{4}$ for selective $\mathrm{CO}_{2}$ reduction to $\mathrm{CH}_{3} \mathrm{OH}$ via facile coupling of $\mathrm{ZnO}$ : A direct $\mathrm{Z}$-scheme mechanism, J Mater Chem A 3: 19936-19947.

86. Solano Rodriguez B, Drummond P, Ekins P (2017) Decarbonizing the EU energy system by 2050: an important role for BECCS, Clim Pol 17: 93-110.

87. Xu Y, Ramanathan V (2017) Well below 2oC: Mitigation strategies for avoiding dangerous to catastrophic climate changes, Proc Natl Acad Sci U.S.A 114: 201618481.

88. Duscha V, Denishchenkova A, Wachsmuth J (2018) Achievability of the Paris Agreement targets in the EU: demand-side reduction potentials in a carbon budget perspective, Clim Pol 3062: 1-14.

89. Fuglestvedt J, Rogelj J, Millar RJ, Allen M, Boucher O, et al. (2018) Implications of possible interpretations of greenhouse gas balance in the Paris Agreement, Philos Trans R Soc A 376: 20160445.

90. Zhou S, Liu Y, Li J, Wang Y, Jiang et al. (2014) Facile in situ synthesis of graphitic carbon nitride (g-C3N4)-N$\mathrm{TiO}_{2}$ heterojunction as an efficient photocatalyst for the selective photoreduction of $\mathrm{CO}_{2}$ to $\mathrm{CO}$, Appl Catal B 158$159,20-29$.

91. Jia J, O'Brien PG, He L, Qiao Q, Fei T, et al. (2016) Visible and Near-Infrared Photothermal Catalyzed Hydrogenation of Gaseous $\mathrm{CO}_{2}$ over Nanostructured $\mathrm{Pd} @ \mathrm{Nb}_{2} \mathrm{O}_{5}$, Adv Sci 3: 1600189 .

92. Meng X, Wang T, Liu L, Ouyang S, Li P, et al. (2014) Photothermal Conversion of $\mathrm{CO} 2$ into $\mathrm{CH} 4$ with $\mathrm{H}-2$ over Group VIII Nanocatalysts: An Alternative Approach for Solar Fuel Production, Angew Chem Int Ed 53: 1147811482.

93. Mateo D, Albero J, Garc'1a H (2018) Graphene supported $\mathrm{NiO} / \mathrm{Ni}$ nanoparticles as efficient photocatalyst for gas phase $\mathrm{CO}_{2}$ reduction with hydrogen, Appl Catal B 224: 563-571.

Copyright: (C2021 Delia Teresa Sponza. This is an open-access article distributed under the terms of the Creative Commons Attribution License, which permits unrestricted use, distribution, and reproduction in anymedium, provided the original author and source are credited. 